\title{
The measurement properties of tests and tools used in cystic fibrosis studies: a systematic review
}

\author{
Charlie McLeod $\mathbb{1}^{1,2,3}$, Jamie Wood ${ }^{4}$, Allison Tong ${ }^{5,6}$, André Schultz ${ }^{7,8}$, Richard Norman ${ }^{9}$, Sherie Smith ${ }^{10}$, \\ Christopher C. Blyth ${ }^{1,2,3,11}$, Steve Webb ${ }^{12,13}$, Alan R. Smyth ${ }^{10}$ and Thomas L. Snelling ${ }^{5,14}$
}

${ }^{1}$ Wesfarmers Centre for Vaccines and Infectious Diseases, Telethon Kids Institute, Nedlands, Australia. ${ }^{2}$ Division of Paediatrics, Faculty of Medicine, University of Western Australia, Nedlands, Australia. ${ }^{3}$ Infectious Diseases Dept, Perth Children's Hospital, Nedlands, Australia. ${ }^{4}$ Physiotherapy Dept, Sir Charles Gairdner Hospital, Nedlands, Australia. ${ }^{5}$ Sydney School of Public Health, The University of Sydney, Sydney, Australia. ${ }^{6}$ Centre for Kidney Research, The Children's Hospital at Westmead, Westmead, Australia. ${ }^{7}$ Wal-yan Respiratory Research Centre, Telethon Kids Institute, University of Western Australia, Nedlands, Australia. ${ }^{8}$ Dept of Respiratory and Sleep Medicine, Perth Children's Hospital, Nedlands, Australia. ${ }^{9}$ School of Population Health, Curtin University, Bentley, Australia. ${ }^{10}$ Evidence Based Child Health Group, University of Nottingham, Queens Medical Centre, Nottingham, UK. ${ }^{11}$ Pathwest Laboratory Medicine WA, QEII Medical Centre, Nedlands, Australia. ${ }^{12}$ St John of God Hospital, Subiaco, Australia. ${ }^{13}$ School of Population Health and Preventive Medicine, Monash University, Melbourne, Australia. ${ }^{14}$ Menzies School of Health Research, Royal Darwin Hospital Campus, Tiwi, Australia.

Corresponding author: Charlie McLeod (charlie.mcleod@health.wa.gov.au)

Shareable abstract (@ERSpublications)

A diverse range of tests and tools were found, these varied with respect to their measurement properties. There was inconsistency in the selection of tests and tools to measure the same/similar outcomes across studies. Consensus is required. https://bit.ly/3nw2uoE

Cite this article as: McLeod C, Wood J, Tong A, et al. The measurement properties of tests and tools used in cystic fibrosis studies: a systematic review. Eur Respir Rev 2021; 30: 200354 [DOI: 10.1183/ 16000617.0354-2020].

Copyright @The authors 2021

This version is distributed under the terms of the Creative Commons Attribution Non-Commercial Licence 4.0. For commercial reproduction rights and permissions contact permissions@ersnet.org

This article has supplementary material available from err.ersjournals.com

Received: 3 Nov 2020 Accepted: 26 Dec 2020

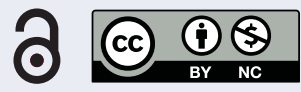

\section{Abstract}

There is no consensus on how best to measure responses to interventions among children and adults with cystic fibrosis (CF). We have systematically reviewed and summarised the characteristics and measurement properties of tests and tools that have been used to capture outcomes in studies among people with CF, including their reliability, validity and responsiveness. This review is intended to guide researchers when selecting tests or tools for measuring treatment effects in CF trials. A consensus set of these tests and tools could improve consistency in how outcomes are captured and thereby facilitate comparisons and synthesis of evidence across studies.

\section{Introduction}

Research is conducted to generate evidence of the efficacy and safety of interventions to inform best clinical practice and thereby improve outcomes for patients. When designing studies, it is necessary to establish which outcomes must be evaluated to meet the study objectives and how these outcomes will be measured and analysed as end-points [1]. Tests or tools may be required for outcome measurement. To improve consistency and facilitate synthesis of evidence across studies, there is a need to establish a consensus set of these tests and tools for measuring outcomes in studies in people with cystic fibrosis (CF). These must be responsive to changes in the outcome of interest and capture outcomes with sufficient validity, reliability and precision [2,3]. This is necessary so that results can be interpreted with confidence and be used to support the translation of evidence into practice.

There is no existing consensus on the selection of tests or tools for measuring outcomes. Selection is challenging for a number of reasons. First, tests and tools may lack appropriation validation, and hence their quality might be uncertain. Secondly, criteria to facilitate interpretation of the results of the test or tool may not exist. Thirdly, logistic or economic constraints may restrict the use of some. Finally, although initiatives to improve and standardise the use of patient-reported outcome measures (PROMs) have been 
established [4, 5], there is no standardised approach for evaluating and selecting optimal tests and tools more generally in clinical research.

As a first step towards developing a consensus set of tests and tools for measuring outcomes in CF studies, we aimed to evaluate and summarise the characteristics and properties of tests and tools that have been used in previous CF studies. In the interim, we hope this review will be used by clinicians, people with $\mathrm{CF}$, researchers and policy makers to guide optimal selection of these tests and tools, and to encourage validation or development of new tests or tools for measurement where required.

\section{Methods}

Search strategy and selection criteria

This was a PROSPERO registered systematic review (CRD42020151785). The search strategy is provided in the supplementary material. Medline, Embase and the Cochrane database were searched from inception until July 2020. Outcome measures proposed for evaluation in the Clinicaltrials.gov registry were also evaluated.

Inclusion criteria were reports of randomised controlled trials, observational studies, conference abstracts and reviews written in English, evaluating one or more measurement properties of a test or tool used to measure health outcomes in studies among people with CF. Original studies were sought to provide additional information about the characteristics or measurement properties of the tests and tools where necessary. Registered trials without published results proposing evaluation of one or more measurement properties of novel tests or tools were also included. Exclusion criteria were tests or tools developed for diagnostic purposes or used for evaluation of microbiological outcomes, or validation studies written in languages other than English. Tests and tools used in people with CF but validated in non-CF populations were beyond the scope of this review.

Titles and abstracts were screened independently by two reviewers (C. McLeod and J. Wood). Potentially eligible studies were downloaded to Endnote and duplicates removed. Full text articles were retrieved and eligibility confirmed by consensus of the reviewers. A third reviewer (T.L. Snelling) was used to confirm eligibility where consensus could not be achieved. Relevant data were extracted by C. McLeod and recorded in an Excel database and cross-checked by J. Wood.

The following characteristics of selected tests or tools were recorded: the outcome construct measured; the target population; mode of administration of the test or tool; recall period (if relevant); time taken to perform the test; the range of possible scores; and the ease of use (feasibility). The following properties of measurement were critically appraised: 1) validity, including content validity, construct validity (including convergent and discriminant performance of the test, the structural validity and cross-cultural validity) and criterion validity (including concurrent and predictive validity); 2) reliability, including the test-retest and inter-/intra-rate reliability, internal consistency and measurement error; 3) responsiveness; and 4) the minimal clinically important difference (MCID). Definitions for these measurement properties were based on those provided by the Consensus-based Standards for the selection of health Measurement INstruments initiative (COSMIN); these are presented in supplementary appendix 1.

\section{Definitions, abbreviations and citations}

Quality of life (QoL) tools were broadly defined as those which capture an individuals' perception of their life satisfaction relative to their goals in the context of their culture and value systems, and not those that capture QoL based solely on the health status of the individual per se (health-related quality of life; HRQoL) [6]. Disease-specific QoL tools were defined as those developed for measuring QoL in people with CF, whereas generic QoL tools were defined as those originally developed for use in other populations that have also been applied in studies involving people with CF.

A full list of abbreviations and their meanings used throughout this manuscript and supplementary materials are alphabetically listed in supplementary appendix 2. References for information presented in the tables throughout this manuscript are provided in the supplementary materials.

\section{Results}

The review process is depicted in figure 1. 118 studies evaluating the measurement properties of 74 tests and tools used in studies among people with CF identified from Medline, Embase or Clinical Trials met the inclusion criteria [7-119]; a summary of these studies is provided in table S3. This review included three registered studies proposing validation of tests or tools used in people with CF with unpublished 


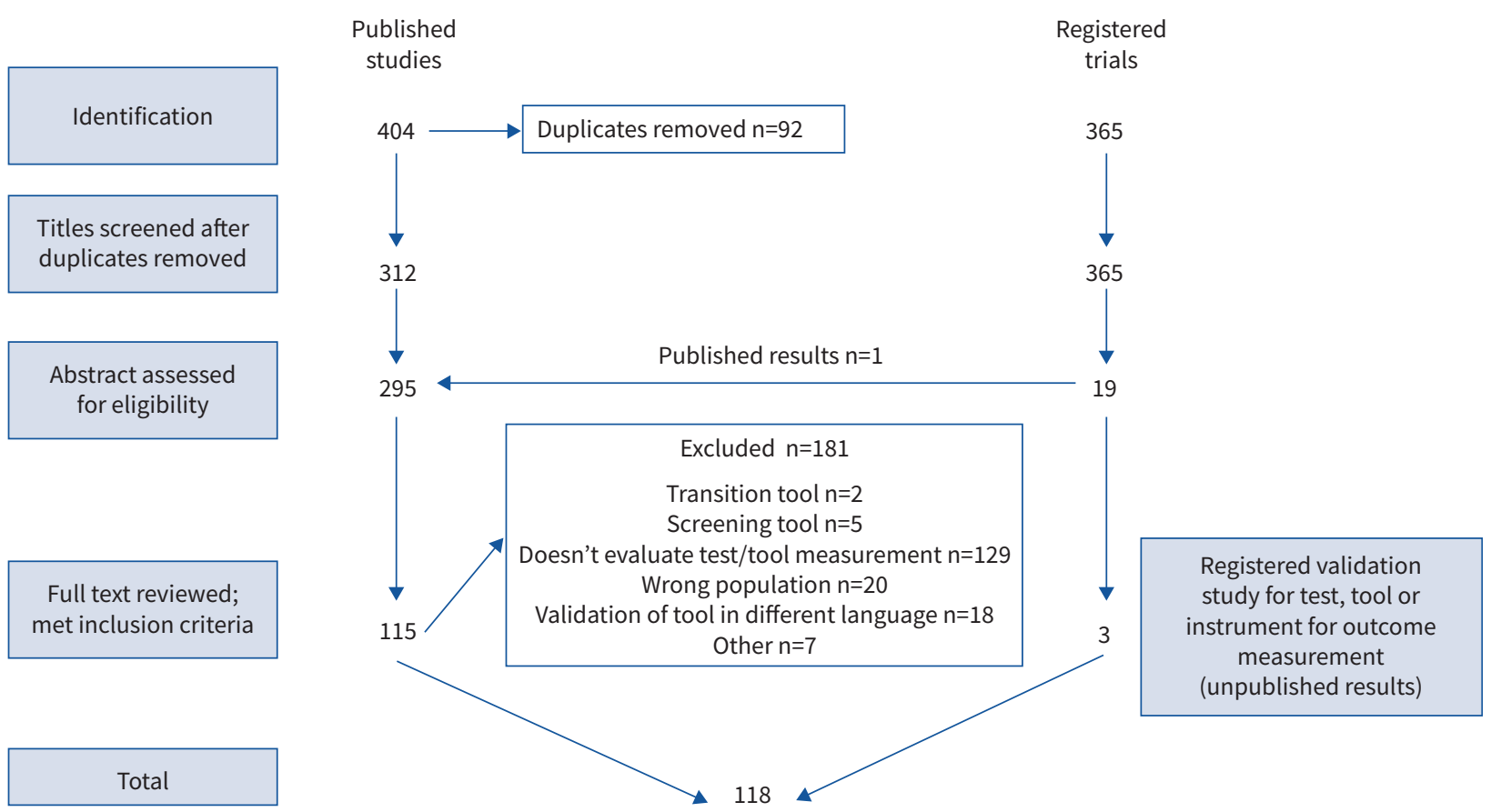

FIGURE 1 Search strategy flow chart.

results [120]. Nine source articles describing the characteristics or measurement properties of tests or tools were also included [121-129].

\section{Characteristics of tests and tools}

Tests or tools were categorised as PROMs capturing QoL or other patient-reported outcomes, clinical scores, radiological scores or tests capturing functional exercise performance, CF transmembrane conductance regulator (CFTR) function or sputum characteristics.

QoL tools

17 generic QoL tools evaluated in CF populations and seven CF-specific QoL were identified. Characteristics of these generic and CF-specific QoL tools are detailed in table S5 and table 1, respectively.

The Cystic Fibrosis Questionnaire-Revised (CFQ-R; original version 2003) has been the most widely used QoL tool reported in CF studies and is available in 34 languages [130]. It is endorsed for use in clinical trials by the US Food and Drug Administration (FDA) and European Medicines Agency [131, 132]. There are five versions available; these are described in table 1.

One QoL questionnaire for use by carers of people with CF was identified, the Carer QoL in CF questionnaire (CQOLCF); this is a 35-item questionnaire designed to evaluate how providing care for someone with CF impacts on a carers’ physical, emotional and social functioning and family [69].

\section{Tools capturing patient-reported outcomes (excluding QoL)}

Six questionnaires designed to evaluate self-reported levels of physical activity were identified [86, 101]. Two questionnaires capturing body image for use in people aged $\geq 14$ years [116] and one tool measuring dietary intake in children aged between 7 months and 12 years (table S5) were also found [40]. One PROM has been used to evaluate the impact of CF on stigma, disclosure, public attitudes and negative self-image among adults with CF and their carers [96]. A separate PROM originally developed for use in people with asthma has been used to capture work productivity and activity in people with CF [92].

12 clinical scores calculated from outcome data reported by people with CF were identified; three were developed for use in CF pulmonary exacerbations $[12,106]$, three captured respiratory symptoms $[22,74$, 
TABLE 1 Characteristics of quality of life (QoL) tools developed for use in people with cystic fibrosis (CF)

\begin{tabular}{|c|c|c|c|c|c|c|c|}
\hline Test or tool & Description & Constructs(s) & $\begin{array}{c}\text { Target } \\
\text { population }\end{array}$ & Administration & $\begin{array}{l}\text { Recall } \\
\text { period }\end{array}$ & $\begin{array}{l}\text { Range of } \\
\text { scores }\end{array}$ & $\begin{array}{l}\text { Feasibility/ } \\
\text { cultural } \\
\text { validity }\end{array}$ \\
\hline CFIQ & $\begin{array}{c}40 \text { items; } 5-6 \text { min to } \\
\text { complete }\end{array}$ & $\begin{array}{c}\text { Activity } \\
\text { limitation } \\
\text { (physical, social, } \\
\text { leisure), school/ } \\
\text { work limitations, } \\
\text { vulnerability/lack } \\
\text { of control, } \\
\text { emotional } \\
\text { impact, } \\
\text { treatment } \\
\text { burden and } \\
\text { future outlook }\end{array}$ & $\begin{array}{l}\text { Children and } \\
\text { adults with CF } \\
\text { and their } \\
\text { carers; } \\
\text { interview } \\
\text { templates for } \\
\text { children aged } \\
6-11 \text { years, } \\
\text { adolescents, } \\
\text { adults } \\
\text { >12 years and } \\
\text { carers of } \\
\text { children aged } \\
0-18 \text { years }\end{array}$ & Paper & $\begin{array}{l}36 \text { items } \\
7 \text { day } \\
\text { recall, the } \\
\text { remainder } \\
\text { "current } \\
\text { status" }\end{array}$ & $\begin{array}{l}\text { 5- or } 7 \text {-point } \\
\text { verbal rating } \\
\text { scale }\end{array}$ & $\begin{array}{l}\text { Largely } \\
\text { developed in } \\
\text { Caucasian } \\
\text { population; } \\
\text { further } \\
\text { validation } \\
\text { required }\end{array}$ \\
\hline CFQoL & $\begin{array}{c}\text { QoL and symptom scoring } \\
\text { tool; } 52 \text { items over nine } \\
\text { domains; } 15-20 \text { min to } \\
\text { complete }\end{array}$ & $\begin{array}{l}\text { Two symptom } \\
\text { scales (chest and } \\
\text { emotional) and } \\
\text { seven QoL } \\
\text { domains: } \\
\text { physical } \\
\text { functioning (10), } \\
\text { social } \\
\text { functioning (4), } \\
\text { treatment issues } \\
\text { (3), future } \\
\text { concerns (6), } \\
\text { interpersonal } \\
\text { relationships } \\
\text { (10), body image } \\
\text { (3), career issues } \\
\text { (4) }\end{array}$ & $\begin{array}{l}\text { Adults and } \\
\text { adolescents }\end{array}$ & Paper & 14 days & $\begin{array}{c}\text { Each } \\
\text { response } \\
\text { 6-point Likert } \\
\text { scale; total } \\
\text { score } 0-100\end{array}$ & $\begin{array}{c}\text { Time } \\
\text { consuming }\end{array}$ \\
\hline $\begin{array}{l}\text { CFQoL scale } \\
\text { (single } \\
\text { item) }\end{array}$ & $\begin{array}{l}\text { VAS: how has CF affected } \\
\text { your QoL in the last } \\
2 \text { weeks? Couple of mins } \\
\text { to complete }\end{array}$ & $\begin{array}{l}\text { Single QoL } \\
\text { question }\end{array}$ & Adults & Paper & 14 days & $0-10$ & $\begin{array}{c}\text { Quick } \\
\text { Validated in } \\
\text { population } \\
\text { who had not } \\
\text { had pulmonary } \\
\text { exacerbation } \\
\text { for past } \\
6 \text { weeks }\end{array}$ \\
\hline CFQ-R & $\begin{array}{l}\text { QoL and symptom scoring } \\
\text { tool; four scales: } 1 \text { ) CFQ-R } \\
\text { >14 years ( } 44 \text { items over } 9 \\
\text { domains); } 2 \text { ) CFQ-R child } \\
\text { (8 domains, } 35 \text { items), } \\
\text { interviewer-administered } \\
6-13 \text { years and self-report } \\
12-13 \text { years; 3) CFQ-R } \\
\text { parent: } 44 \text { items, } 10 \text { min; } \\
\text { 4) preschool 3-6 years, } 28 \\
\text { items, } 15 \text { min to complete }\end{array}$ & $\begin{array}{c}\text { Activity } \\
\text { limitation } \\
\text { (physical, social, } \\
\text { leisure), school/ } \\
\text { work limitations, } \\
\text { vulnerability, lack } \\
\text { of control, } \\
\text { emotional } \\
\text { impact, } \\
\text { treatment } \\
\text { burden and } \\
\text { future outlook }\end{array}$ & $\begin{array}{c}\text { CFQ-R } \\
\text { >14 years; } \\
\text { CFQ-R child: } \\
\text { interviewer- } \\
\text { administered } \\
\text { 6-13 years and } \\
\text { self-report } \\
\text { 12-13 years } \\
\text { CFQ-R parent: } \\
\text { proxy report } \\
\text { for children } \\
\text { 6-13 years } \\
\text { Separate are } \\
\text { not proxy } \\
\text { report for } \\
\text { children } \\
\text { 4-60 months }\end{array}$ & $\begin{array}{l}\text { Paper/ } \\
\text { electronic }\end{array}$ & 14 days & $\begin{array}{l}\text { 4-point Likert } \\
\text { scale; total } \\
\text { score 0-100 }\end{array}$ & $\begin{array}{c}\text { Most widely } \\
\text { used HRQoL } \\
\text { questionnaire } \\
\text { in CF; } \\
\text { translated into } \\
34 \text { languages; } \\
\text { EMA/FDA } \\
\text { supports use } \\
\text { in clinical trials }\end{array}$ \\
\hline
\end{tabular}




\begin{tabular}{|c|c|c|c|c|c|c|c|}
\hline Test or tool & Description & Constructs(s) & $\begin{array}{c}\text { Target } \\
\text { population }\end{array}$ & Administration & $\begin{array}{l}\text { Recall } \\
\text { period }\end{array}$ & $\begin{array}{l}\text { Range of } \\
\text { scores }\end{array}$ & $\begin{array}{l}\text { Feasibility/ } \\
\text { cultural } \\
\text { validity }\end{array}$ \\
\hline eCF-QUEST & $\begin{array}{c}\text { Electronic, } 3 \text { domains, } \\
4 \text { items }\end{array}$ & $\begin{array}{l}\text { Global measure } \\
\text { (40 items), } \\
\text { gastrointestinal } \\
\text { ( } 5 \text { items) and } \\
\text { general health } \\
\text { ( } 2 \text { items) }\end{array}$ & Adults & $\begin{array}{l}\text { Paper/ } \\
\text { electronic }\end{array}$ & NR & NR & NR \\
\hline DISABKIDS-CF & $\begin{array}{l}6 \text { items, } 2 \text { min to } \\
\text { complete }\end{array}$ & $\begin{array}{c}\text { Impact and } \\
\text { treatment } \\
\text { dimensions }\end{array}$ & $\begin{array}{l}\text { Exclusively for } \\
\text { use in children } \\
\text { and } \\
\text { adolescents } \\
8-17 \text { years; } \\
\text { self-report and } \\
\text { proxy version } \\
\text { (carer) }\end{array}$ & Paper & $\begin{array}{c}\text { Each } \\
\text { dimension } \\
0-100\end{array}$ & $\begin{array}{l}\text { 5-point Likert } \\
\text { scale; scores } \\
\text { 0-100\% } \\
\text { (higher } \\
\text { score=higher } \\
\text { QoL) }\end{array}$ & $\begin{array}{l}\text { English and } \\
\text { Spanish } \\
\text { versions }\end{array}$ \\
\hline FLZ-CF & $\begin{array}{l}\text { Healthy and general } \\
\text { patient population; } 18 \\
\text { items over } 8 \text { domains, } \\
\text { 9-item weighted scale, } \\
5 \text { min to complete }\end{array}$ & $\begin{array}{l}9 \text { items: cough/ } \\
\text { dyspnoea, } \\
\text { abdominal, } \\
\text { sleep, eating, } \\
\text { therapy routine, } \\
\text { adherence, } \\
\text { understanding } \\
\text { by others, being } \\
\text { needed by } \\
\text { others, } \\
\text { disadvantage }\end{array}$ & $\begin{array}{l}\text { Adolescents } \\
\text { >15 years and } \\
\text { adults }\end{array}$ & Paper & 28 days & $\begin{array}{l}\text { 0-100 (high } \\
\text { score=high } \\
\text { satisfaction) }\end{array}$ & Screening test \\
\hline CQOLCF & $\begin{array}{c}35 \text { item carer QoL } \\
\text { instrument, }<10 \text { minutes }\end{array}$ & $\begin{array}{c}\text { Physical, } \\
\text { emotional, family } \\
\text { and social } \\
\text { functioning }\end{array}$ & $\begin{array}{c}\text { Carers of } \\
\text { people with CF }\end{array}$ & Paper & NR & $\begin{array}{c}\text { Each } \\
\text { response } \\
\text { 5-point Likert } \\
\text { scale }\end{array}$ & NR \\
\hline
\end{tabular}

CFIQ: CF impact questionnaire; CFQoL: CF QoL; CFQ-R: revised CF questionnaire; eCF-QUEST: electronic version of the CFQoL evaluative self-administered test; FLZ-CF: Questions of Life Satisfaction; CQOLCF: caregiver QoL CF scale; VAS: visual analogue scale; HRQoL: health-related QoL; EMA: European Medicines Association; FDA: US Food and Drug Administration; NR: not reported.

85, 101, 115], three characterised pain [90, 133], two quantified abdominal symptoms [28, 31, 41] and one has been used to evaluate physical and psychological symptom burden [105, 106] (table 2). Of these, the CFRSD-CRISS (chronic respiratory infection symptom score) has been the most widely used in CF studies and is available in 38 languages; it evaluates eight respiratory symptoms and is validated for use in people with $\mathrm{CF}$ aged $\geq 12$ year [44].

\section{Clinical scores}

The modified Schwachman scale (first described in 1964) was developed as a longitudinal clinical assessment tool. It includes activity levels, chest findings, cough, growth, nutrition, the character of stool and radiological changes; lung function is not included in this measure [26]. A test developed by RADINE et al. [45] measuring nocturnal cough over two consecutive nights was found to be safe and feasible.

Three prognostic scoring tools were found. The most recent, in 2004, was a 5-year survival prediction tool [63], which was designed to guide eligibility for lung transplant; survival is predicted based on age, sex, forced expiratory volume in $1 \mathrm{~s}$ ( $\mathrm{FEV}_{1} \%$ pred), weight for age z-score, pancreatic function, presence of diabetes, infection with Staphylococcus aureus or Burkholderi cepacia and the annual number of pulmonary exacerbations. The second, the modified Huang score (first described in 1997) [26], was developed for use as a prognostic and longitudinal assessment tool for those with terminal disease and captures clinical features (including lung function), radiological features and complications of disease. The oldest tool, first described in 1973, is the National Institutes of Health score (NIH) [26, 108], which was developed for people aged 5-30 years. It predicts the probability of death within 3 years based on lung function, chest radiograph (CXR) changes, and physiological and psychological features. 
TABLE 2 Scoring tools incorporating patient-reported outcome

\begin{tabular}{|c|c|c|c|c|c|c|c|}
\hline Test or tool & Description & Constructs(s) & $\begin{array}{c}\text { Target } \\
\text { population }\end{array}$ & Administration & $\begin{array}{l}\text { Recall } \\
\text { period }\end{array}$ & $\begin{array}{l}\text { Range of } \\
\text { scores }\end{array}$ & $\begin{array}{c}\text { Feasibility/cultural } \\
\text { validity }\end{array}$ \\
\hline \multicolumn{8}{|l|}{$\begin{array}{l}\text { Pulmonary } \\
\text { exacerbations }\end{array}$} \\
\hline AWESCORE & $\begin{array}{l}5 \text { domains, each } \\
\text { with } 2 \text { items }\end{array}$ & $\begin{array}{l}\text { Respiratory (cough } \\
\text { and sputum), physical } \\
\text { (energy and exercise), } \\
\text { nutritional (appetite } \\
\text { and weight), } \\
\text { psychological (mood } \\
\text { and anxiety) and } \\
\text { general health } \\
\text { "wellness" and sleep }\end{array}$ & Adults & Paper & NR & $0-100$ & NR \\
\hline $\begin{array}{l}\text { CFRSD/ } \\
\text { CFRSD-CRISS }\end{array}$ & $\begin{array}{l}\text { Symptom score: } \\
\text { respiratory and } \\
\text { emotional items } \\
\text { (respiratory only in } \\
\text { short version); } \\
\text { developed for } \\
\text { pulmonary } \\
\text { exacerbation }\end{array}$ & $\begin{array}{c}8 \text { respiratory } \\
\text { symptoms, } 4 \\
\text { emotional items and } 4 \\
\text { other items (or } \\
\text { short-version } \\
\text { CFRSD-CRISS; } 8 \\
\text { respiratory items: } \\
\text { difficulty breathing, } \\
\text { fever, tired, mucus, } \\
\text { chills/sweats, cough, } \\
\text { mucus, chest } \\
\text { tightness, wheezing) }\end{array}$ & $>12$ years & $\begin{array}{l}\text { Paper/ } \\
\text { electronic }\end{array}$ & Daily & $\begin{array}{c}3-4 \text { point } \\
\text { Likert scale, } \\
\text { total score } \\
0-100\end{array}$ & $\begin{array}{c}\text { Available in } 38 \\
\text { languages }\end{array}$ \\
\hline $\begin{array}{l}\text { Symptom } \\
\text { score system }\end{array}$ & $\begin{array}{c}4 \text { items; pulmonary } \\
\text { exacerbation } \\
\text { assessment }\end{array}$ & $\begin{array}{l}\text { Cough, sputum } \\
\text { volume and viscosity, } \\
\text { breathlessness, fatigue }\end{array}$ & Adults & Paper & Daily & $\begin{array}{c}\text { 4-point } \\
\text { Likert scale }\end{array}$ & NR \\
\hline \multicolumn{8}{|l|}{ Respiratory } \\
\hline ReS-CF & $\begin{array}{c}\text { 4-item } \\
\text { questionnaire; } \\
<1 \text { min to complete }\end{array}$ & $\begin{array}{l}\text { Self-reported VAS for } \\
\text { respiratory symptoms, } \\
\text { cough, chest } \\
\text { congestion and } \\
\text { sputum }\end{array}$ & Adults & Paper & NR & $\begin{array}{l}\text { Each VAS } \\
\text { scored } \\
\text { separately } \\
0-10 \text { (worst) }\end{array}$ & $\begin{array}{l}\text { Screening tool: } \\
\text { respiratory } \\
\text { symptoms }\end{array}$ \\
\hline SOBQ & $\begin{array}{l}\text { Developed for PEX } \\
\text { assessment; } 17 \\
\text { items ( } 13 \\
\text { respiratory and } 4 \\
\text { CF-related impacts) }\end{array}$ & $\begin{array}{c}0-6 \text { years and } \\
7-11 \text { years }\end{array}$ & & NR & NR & $\begin{array}{c}\text { Not } \\
\text { applicable }\end{array}$ & \\
\hline SOBQ & $\begin{array}{l}24 \text { items; patients } \\
\text { with COPD, CF and } \\
\text { lung transplant } \\
\text { recipients }\end{array}$ & $\begin{array}{l}\text { Measures SOB while } \\
\text { performing activities } \\
\text { of daily living }\end{array}$ & Adults & Paper & NR & $\begin{array}{l}\text { 5-point } \\
\text { Likert scale } \\
\text { for each } \\
\text { response; } \\
\text { scores 0-120 } \\
\text { (worst) }\end{array}$ & NR \\
\hline \multicolumn{8}{|l|}{ Pain } \\
\hline BPI & $\begin{array}{l}\text { Severity and impact } \\
\text { of pain on daily } \\
\text { functions in people } \\
\text { with chronic } \\
\text { diseases; short: } \\
5 \text { min, long: } 10 \text { min } \\
\text { to complete }\end{array}$ & $\begin{array}{l}7 \text { domains: general } \\
\text { activity, mood, } \\
\text { walking ability, normal } \\
\text { work (including } \\
\text { housework), } \\
\text { relationships with } \\
\text { others, sleep, } \\
\text { enjoyment in life }\end{array}$ & Adults & Paper & Daily & NR & $\begin{array}{c}\text { Psychometrically } \\
\text { and linguistically } \\
\text { validated in } 24 \\
\text { languages }\end{array}$ \\
\hline DPAQ-CF & 7 items & $\begin{array}{c}\text { Frequency, duration, } \\
\text { intensity, location and } \\
\text { coping response to } \\
\text { pain }\end{array}$ & $\begin{array}{l}\text { Adolescents } \\
\text { and adults }\end{array}$ & $\begin{array}{c}\text { Paper/ } \\
\text { electronic }\end{array}$ & Daily & $\begin{array}{l}\text { 5-point } \\
\text { Likert scale } \\
\text { for each } \\
\text { response; } \\
\text { total score } \\
\quad 0-10\end{array}$ & NR \\
\hline
\end{tabular}




\begin{tabular}{|c|c|c|c|c|c|c|c|}
\hline Test or tool & Description & Constructs(s) & $\begin{array}{c}\text { Target } \\
\text { population }\end{array}$ & Administration & $\begin{array}{l}\text { Recall } \\
\text { period }\end{array}$ & $\begin{array}{l}\text { Range of } \\
\text { scores }\end{array}$ & $\begin{array}{c}\text { Feasibility/cultural } \\
\text { validity }\end{array}$ \\
\hline MPI & $\begin{array}{l}52 \text { items, } 3 \\
\text { domains, } 12 \\
\text { subscales; } \\
\text { 15-30 min to } \\
\text { complete }\end{array}$ & $\begin{array}{l}\text { Pain experiences, } \\
\text { responses of others to } \\
\text { the patient's } \\
\text { communicated pain, } \\
\text { the extent to which } \\
\text { patients participate in } \\
\text { activities of daily living }\end{array}$ & $\begin{array}{l}18-64 \text { years } \\
\text { and }>65 \\
\text { years } \\
\text { versions }\end{array}$ & Paper & NR & NR & $\begin{array}{c}\text { Available in } 6 \\
\text { languages }\end{array}$ \\
\hline \multicolumn{8}{|l|}{ Abdominal } \\
\hline CF-Abd score & $\begin{array}{l}\text { 28-item PROM for } \\
\text { assessment of } \\
\text { gastrointestinal } \\
\text { involvement }\end{array}$ & $\begin{array}{l}\text { Abdominal pain, } \\
\text { appetite, bowel } \\
\text { movement and } \\
\text { symptom-related QoL }\end{array}$ & $>6$ years & Paper & 14 days & NR & NR \\
\hline $\begin{array}{l}\text { Gastrointestinal } \\
\text { symptom } \\
\text { tracker }\end{array}$ & $\begin{array}{c}\text { PROM for } \\
\text { assessment of } \\
\text { gastrointestinal and } \\
\text { nutritional issues }\end{array}$ & $\begin{array}{l}4 \text { domains; abdominal } \\
\text { pain, stools, eating } \\
\text { challenges and } \\
\text { adherence }\end{array}$ & $\begin{array}{l}\text { Adolescents } \\
\text { and adults }\end{array}$ & $\begin{array}{l}\text { Electronic } \\
\text { (iPad) }\end{array}$ & $\begin{array}{c}10- \\
14 \text { days }\end{array}$ & $\begin{array}{l}0-100 \\
\text { (worst) }\end{array}$ & $\begin{array}{l}\text { Easy to administer } \\
\text { and complete }\end{array}$ \\
\hline \multicolumn{8}{|l|}{$\begin{array}{l}\text { Symptoms } \\
\text { involving } \\
\text { multiple } \\
\text { systems }\end{array}$} \\
\hline MSAS-CF & $\begin{array}{l}\text { Physical and } \\
\text { psychological } \\
\text { symptom burden }\end{array}$ & $\begin{array}{l}\text { QoL: respiratory ( } 6 \\
\text { items), psychological } \\
\text { burden ( } 5 \text { items) and } \\
\text { gastrointestinal (4 } \\
\text { items) }\end{array}$ & Adults & Paper & 7 days & $\begin{array}{l}\text { Each } \\
\text { symptom 4- } \\
\text { or 5-point } \\
\text { Likert scale }\end{array}$ & $\begin{array}{l}\text { Previously validated } \\
\text { in people with } \\
\text { cancer, heart } \\
\text { disease, HIV and } \\
\text { critical illness }\end{array}$ \\
\hline
\end{tabular}

AWESCORE: Alfred Wellness Score; CFRSD: cystic fibrosis (CF) respiratory symptom diary; CRISS: chronic respiratory infection symptom score; ReS-CF: respiratory symptoms in CF tool; SOBQ: Shortness of Breath Questionnaire; BPI: brief pain inventory; DPAQ-CF : Daily Pain Assessment Questionnaire in CF; MPI: multidimensional pain inventory; CF-Abd: CF abdominal; MSAS: Memorial Symptom Assessment Scale; NR: not reported; VAS: visual analogue scale; PEX: pulmonary exacerbation of CF; SOB: shortness of breath; PROM: patient-reported outcome measures; QoL: quality of life.

\section{Lung function tests}

Tests used to measure lung function for which measurement properties were described include spirometry, raised volume rapid thoracic compression (RVRTC), impulse oscillometry and lung clearance index (LCI). Characteristics of these tests are reported in table S5.

Spirometry has been the most frequently used lung function test in CF studies, and the measure of lung function most commonly reported has been $\mathrm{FEV}_{1}$ [30]. This has been variously measured as the crude volume (in litres) or as the percentage predicted volume for age and height, or z-score for age, sex, height and ethnicity; within-individual changes in the $\mathrm{FEV}_{1}$ have been reported as either the absolute change, or change relative to the baseline measure [54, 72].

\section{Imaging scoring tools}

Four CXR scoring systems used to quantify the degree of structural lung disease were identified. The oldest, the Chrispin-Norman score in 1974, is based on chest configuration and the presence or absence of different types of "shadows" [123]. First described in 1979, the Brasfield or Birmingham score (scored between 3 and 25) aims to capture radiographic evidence of air trapping, bronchial wall thickening, bronchiectasis, atelectasis and general severity [73, 122]. From 1993, the Wisconsin score (0-100) has been used to evaluate six attributes including hyperinflation, peribronchial thickening, bronchiectasis, opacities and atelectasis [54, 129]. The Brasfield scoring system has been reported to be easier to use and quicker to perform than the Wisconsin score [73]. The Northern score (introduced in 1994) is calculated based on the presence of linear, cystic or confluent opacities in each lung quadrant rated on a four-point Likert scale (normal to very severe) on a single film [124].

Three computed tomography (CT) scoring tools were identified: the Brody score (I and II), originally developed in 1999, and the CF-CT score (introduced in 2011), which is based on the Brody II score and 
aims to improve standardisation of the latter [111]. These tools have been used in people aged $>5$ years. In 2014, the Perth Rotterdam Annotated Grid Morphometric Analysis method (PRAGMA-CT) score was developed for application in children and infants [102] and takes an experienced person $\sim 30$ min to calculate per CT scan [111].

Scoring tools based on quantitative magnetic resonance imaging (MRI) are still in development [54].

\section{Functional exercise performance}

The most frequently studied field exercise test performed in people with CF is the 6-min walk test (6MWT) [36]. Characteristics of tests used to measure functional exercise performance are summarised in table 3.

\section{CFTR function}

Characteristics of tests used to directly (e.g. sweat chloride tests) or indirectly (e.g. nasal potential difference tests) measure CFTR function are summarised in supplementary table S5.

Sputum tests

Rheometry tests which capture the characteristics of sputum, and tests used to capture markers of inflammation in sputum, are summarised in table S5.

\section{Measurement properties of tests, tools or instruments}

QoL tools

The measurement properties of generic QoL tools based on their evaluation in CF populations are detailed in table S6, and the properties of CF-specific QoL tools are summarised in table 4.

The development of the CFQ-R involved people with CF, and it has been shown to be reliable, with sound content (including face) validity. The tool has been shown to have good internal consistency for all constructs examined, including parent proxy report of physical, eating and respiratory subscales $(\alpha=0.73$ 0.86), but not for treatment burden ( $\mathrm{r}=0.44)$. The CFQ-R score correlates with $\mathrm{FEV}_{1}$ and body mass index, and discriminates different degrees of disease severity [130], but a correlation with mortality has not been reported. Based on clinician judgement, a change of 0.8 units in the CFQ-R score was considered the MCID in the context of treatment for pulmonary exacerbations [134].

\section{Patient-reported symptoms and function}

The measurement properties of patient-reported symptoms and function are summarised in table 5.

\section{Clinical scores}

A validation study that evaluated nocturnal cough as an outcome found people with CF coughed more than healthy subjects $(\mathrm{p}<0.001)$; the reliability for repeated measurements was higher when cough epochs were scored (multiple coughs with $<2 \mathrm{~s}$ between individual coughs) compared to discrete coughs (internal consistency coefficient (ICC) 0.75 versus 0.49 , respectively) [45].

The interobserver reliability of the modified Schwachman score captured as Pearson's $\mathrm{r}$ coefficient was $0.71,0.64$ and 0.85 for the history, examination and growth domains, respectively [26]; the correlation was 0.92 with the NIH score and 0.67 with $\mathrm{FEV}_{1}$.

The internal consistency of the modified Huang score was reported to be $\alpha=0.6$ (except the domain relating to complications). The correlation of this score with $\mathrm{FEV}_{1} \%$ pred in moderate (score $35-60, \mathrm{r}^{2}=0.3$ ) and severe disease ( $<35$ points, $\mathrm{r}^{2}=0.43$ ) was greater than in asymptomatic or mild disease [26]. The NIH score was found to be significantly lower in the 5 years before death compared to CF controls who did not die $(p<0.001)$; those with a score between 61 and 70 had a 25\% chance of dying within 3 years. The internal consistency of this score was reported to be $\alpha=0.81$ and the inter-rater (Pearson's r) score was 0.90; this was predominantly attributed to the robustness of the pulmonary domain on subscale analysis [26].

\section{Lung function tests}

Low $\mathrm{FEV}_{1}$ was shown to correlate with death, with a relative risk of death within 2 years of 2.0 (95\% CI 1.9-2.2) for each $10 \%$ reduction in $\mathrm{FEV}_{1}$ below the predicted value after adjustment for age and sex [126]. Among people with the same $\mathrm{FEV}_{1}$, the risk of death was more than double for females compared to males (RR 2.2 (95\% CI 1.6-3.1)). FEV 1 was also shown to correlate with QoL; a 5\% change in $\mathrm{FEV}_{1}$ was associated with a change in CFQ-R score from 0.5 to 2.3 points [125]. 


\section{TABLE 3 Functional measures of exercise capacity}

\begin{tabular}{|c|c|c|c|c|c|c|c|}
\hline $\begin{array}{l}\text { Test or } \\
\text { tool }\end{array}$ & Description & Construct(s) & $\begin{array}{l}\text { Target } \\
\text { population }\end{array}$ & Administration & $\begin{array}{l}\text { Recall } \\
\text { period }\end{array}$ & $\begin{array}{l}\text { Range of } \\
\text { scores }\end{array}$ & $\begin{array}{l}\text { Feasibility/ } \\
\text { cultural validity }\end{array}$ \\
\hline iSTEP & $\begin{array}{c}\text { Externally paced test; } \\
\text { speed increases every } \\
2 \text { min Expired gas analysis }\end{array}$ & Expired gas analysis & $\begin{array}{l}\text { Younger, } \\
\text { fitter } \\
\text { patients }\end{array}$ & $\begin{array}{l}\text { Performance } \\
\text { test }\end{array}$ & $10 \mathrm{~min}$ & Variable & $\begin{array}{c}\text { Portable, } \\
\text { standardised and } \\
\text { easy to } \\
\text { administer field } \\
\text { exercise test }\end{array}$ \\
\hline MSWT & $\begin{array}{l}\text { 15-level modification of } \\
\text { ISWT } \\
\text { Office based walk/run test }\end{array}$ & Peak oxygen uptake & Children & $\begin{array}{c}\text { Performance } \\
\text { test; standard } \\
\text { protocol }\end{array}$ & $20 \mathrm{~min}$ & NA & $\begin{array}{l}10 \mathrm{~m} \text { required, } \\
\text { used in younger } \\
\text { and fitter } \\
\text { patients } \\
\text { Excludes those } \\
\text { with i.v. lines or } \\
\text { those requiring } \\
\text { oxygen support }\end{array}$ \\
\hline Power $_{\text {STS }}$ & $\begin{array}{l}\text { 1-min sit-to-stand power } \\
\text { index }\end{array}$ & Quadriceps power & $\begin{array}{l}\text { Moderate- } \\
\text { severe CF }\end{array}$ & $\begin{array}{l}\text { Performance } \\
\text { test; standard } \\
\text { protocol }\end{array}$ & $1 \mathrm{~min}$ & N/A & $\begin{array}{l}\text { Quick and easy } \\
\text { to perform }\end{array}$ \\
\hline $\begin{array}{l}\text { Triple hop } \\
\text { distance }\end{array}$ & $\begin{array}{c}\text { Starting at one end of a } \\
\text { tape, asked to hop three } \\
\text { times consecutively on } \\
\text { dominant leg, trying to } \\
\text { cover as much distance as } \\
\text { possible }\end{array}$ & $\begin{array}{l}\text { Lower extremity } \\
\text { power }\end{array}$ & $\begin{array}{l}\text { Older } \\
\text { children } \\
\text { and adults }\end{array}$ & $\begin{array}{l}\text { Performance } \\
\text { test }\end{array}$ & NR & $\begin{array}{l}\text { Distance } \\
\text { recorded in } \\
\mathrm{cm}\end{array}$ & NR \\
\hline $\begin{array}{l}\text { Vertical } \\
\text { jump } \\
\text { test }\end{array}$ & $\begin{array}{l}90-\mathrm{cm}^{2} \text { mat connected to a } \\
\text { timer next to a wall; time } \\
\text { off mat converted to a } \\
\text { vertical jump ( } \mathrm{cm}) \text { using a } \\
\text { controlled ( } 90 \text { degree) and } \\
\text { uncontrolled knee angle }\end{array}$ & Power and posture & $\begin{array}{l}\text { Older } \\
\text { children } \\
\text { and adults }\end{array}$ & $\begin{array}{l}\text { Performance } \\
\text { test }\end{array}$ & NR & $\begin{array}{l}\text { Vertical } \\
\text { distance } \\
\text { recorded in } \\
\mathrm{cm}\end{array}$ & NR \\
\hline 3MST & $\begin{array}{l}\text { Submaximal stress test } \\
\text { (distance covered in } \mathrm{m} \text { ) }\end{array}$ & $\begin{array}{l}\text { Externally paced test } \\
\text { (metronome paced at } \\
12 \text { beats } \min ^{-1} \text { ) step } \\
\text { up and down a } 6 \text {-inch } \\
\text { step for } 3 \text { min }\end{array}$ & $\begin{array}{c}\text { Good } \\
\text { choice in } \\
\text { severe CLD }\end{array}$ & $\begin{array}{l}\text { Performance } \\
\text { test; standard } \\
\text { protocol }\end{array}$ & $3 \mathrm{~min}$ & NA & $\begin{array}{l}\text { Requires the } \\
\text { least amount of } \\
\text { space; } 6 \text {-inch } \\
\text { step required }\end{array}$ \\
\hline 6MWT & $\begin{array}{l}\text { Submaximal stress test } \\
\text { (distance covered in } \mathrm{m} \text { ) }\end{array}$ & $\begin{array}{l}\text { Standard protocol; } \\
\text { distance walked } \\
\text { within } 6 \text { min (enough } \\
\mathrm{O}_{2} \text { to maintain } \\
\text { saturations }>90 \% \text { ) }\end{array}$ & $\begin{array}{l}\text { Validated in } \\
7-23 \text { years } \\
\text { Good } \\
\text { choice in } \\
\text { severe CLD }\end{array}$ & $\begin{array}{l}\text { Performance } \\
\text { test; standard } \\
\text { protocol }\end{array}$ & $6 \mathrm{~min}$ & NA & $\begin{array}{c}\text { Most frequently } \\
\text { studied exercise } \\
\text { test in CF; easy } \\
\text { but requires } \\
30 \mathrm{~m}\end{array}$ \\
\hline $\begin{array}{l}30 \text { s or } \\
\text { 1-min- } \\
\text { STS }\end{array}$ & $\begin{array}{c}\text { Cardiorespiratory response } \\
\text { during a } 30 \text {-s or } 1 \text {-min STS } \\
\text { test (chair height } 40 \mathrm{~cm} \\
\text { without armrest; full knee } \\
\text { extension); as many } \\
\text { repetitions as possible in } \\
1 \mathrm{~min}\end{array}$ & Exercise capacity & $\begin{array}{l}\text { Moderate- } \\
\text { severe CF }\end{array}$ & $\begin{array}{c}\text { Performance } \\
\text { test; standard } \\
\text { protocol }\end{array}$ & $1 \mathrm{~min}$ & $\begin{array}{l}\text { Total number } \\
\text { of full } \\
\text { repetitions in } \\
30 \mathrm{~s} \text { or } 1 \mathrm{~min}\end{array}$ & $\begin{array}{l}\text { Quick and easy } \\
\text { to perform }\end{array}$ \\
\hline
\end{tabular}

iSTEP: incremental field step test; MSWT: modified shuttle walk test; Power $_{\text {STs: }}$ 1-min sit-to-stand power index; 3MST: 3-min sit-to-stand test; 6MWT: 6-min walk test; STS: sit-to-stand test; ISWT: incremental shuttle walk test; N/A: not applicable; CF: cystic fibrosis; CLD: chronic lung disease.

The RVRTC test demonstrated good test-retest reliability with a coefficient of variation reported to be 2-6\%; it differentiated people with CF from healthy controls, including among children aged $<6$ years [91]. Parameters were shown to improve in children aged between 4 months and 1 year, raising the possibility that lung damage may be reversible during this time [91]. However, RVRTC testing has not been appropriately standardised and consequently has not yet been recommended by authoritative bodies such as the European CF Society Clinical Trial Network as a primary outcome measure for use in CF studies [32].

Measurement of LCI has been found to be reliable, valid and responsive during treatment of pulmonary exacerbations and for monitoring disease progression [23, 37, 89, 110]. Measurements obtained by $\mathrm{N}_{2}$ washout and by $\mathrm{SF}_{6}$ were comparable (limits of agreement -2.5 to 1.2) [23]. These tests were found to 
TABLE 4 Measurement properties of quality of life (QoL) tools specific for people with cystic fibrosis (CF)

\begin{tabular}{|c|c|c|c|c|c|c|c|c|c|c|}
\hline Test or tool & $\begin{array}{l}\text { Content } \\
\text { validity }\end{array}$ & $\begin{array}{c}\text { Convergent } \\
\text { validity }\end{array}$ & $\begin{array}{l}\text { Discriminant } \\
\text { validity }\end{array}$ & Concurrent & Predictive & $\begin{array}{l}\text { Intra- or } \\
\text { inter-rater } \\
\text { and } \\
\text { test-retest }\end{array}$ & $\begin{array}{c}\text { Internal } \\
\text { consistency }\end{array}$ & $\begin{array}{l}\text { Measurement } \\
\text { error }\end{array}$ & Responsiveness & $\begin{array}{c}\text { Comments } \\
\text { MCID }\end{array}$ \\
\hline CFIQ & $\begin{array}{c}\text { Demonstrated; } \\
\text { people }>6 \text { years } \\
\text { with CF and } \\
\text { carers used in } \\
\text { construction }\end{array}$ & NR & NR & NR & NR & NR & NR & NR & NR & $\begin{array}{l}\text { Requires } \\
\text { further } \\
\text { validation; } \\
\text { content } \\
\text { validity } \\
\text { established }\end{array}$ \\
\hline CFQoL & $\begin{array}{l}\text { Easy to } \\
\text { understand/ } \\
\text { complete; } \\
\text { people with CF } \\
\text { involved in } \\
\text { construction }\end{array}$ & $\begin{array}{c}\text { Correlation of } \\
\text { emotional } \\
\text { scores with } \\
\text { SF-36 } r=0.64 \text {; } \\
\text { p }<0.001\end{array}$ & $\begin{array}{l}\text { Chest and } \\
\text { emotional } \\
\text { scores } \\
\text { distinguished } \\
\text { between } \\
\text { severity of } \\
\text { chronic lung } \\
\text { disease }\left(\mathrm{FEV}_{1} \%\right. \\
\text { pred }>70,40-70 \\
\text { or }<40)\end{array}$ & $\begin{array}{l}\text { Chest score } \\
\text { correlation with } \\
\mathrm{FEV}_{1} \text { not tested }\end{array}$ & NR & $\begin{array}{c}\text { Test-retest } \\
\mathrm{r}_{\mathrm{s}}=0.74-0.94 \\
(\mathrm{p}<0.01) \\
\text { Robust } \\
\text { after } 7- \\
10 \text { days; } 0.9 \\
\text { for } \\
\text { emotional } \\
\text { scores and } \\
0.93 \text { for } \\
\text { respiratory }\end{array}$ & $\begin{array}{c}\text { Cronbach's } \\
\alpha=0.3\end{array}$ & NR & $\begin{array}{l}\text { Chest symptom } \\
\text { scores increased } \\
\text { during } \\
\text { pulmonary } \\
\text { exacerbation } \\
\text { treatment } \\
\text { Chest and } \\
\text { emotional score } \\
\text { responsive over a } \\
\text { 2-week } \\
\text { application } \\
\text { period in } \\
\text { hospital ( } 47-70.3 \text {, } \\
\text { p=0.006) versus } \\
\text { home groups } \\
\text { (49.7-68.8, } \\
\text { p=0.03) }\end{array}$ & NR \\
\hline
\end{tabular}




\begin{tabular}{|c|c|c|c|c|c|c|c|c|c|c|}
\hline Test or tool & $\begin{array}{l}\text { Content } \\
\text { validity }\end{array}$ & $\begin{array}{l}\text { Convergent } \\
\text { validity }\end{array}$ & $\begin{array}{l}\text { Discriminant } \\
\text { validity }\end{array}$ & Concurrent & Predictive & $\begin{array}{l}\text { Intra- or } \\
\text { inter-rater } \\
\text { and } \\
\text { test-retest }\end{array}$ & $\begin{array}{c}\text { Internal } \\
\text { consistency }\end{array}$ & $\begin{array}{l}\text { Measurement } \\
\text { error }\end{array}$ & Responsiveness & $\begin{array}{c}\text { Comments/ } \\
\text { MCID }\end{array}$ \\
\hline CFQ-R & $\begin{array}{c}\text { Patients } \\
\text { involved in } \\
\text { testing clarity } \\
\text { of items } \\
\text { Preschool } \\
\text { version: } \\
\text { children able to } \\
\text { understand and } \\
\text { answer } \\
\text { questions }\end{array}$ & $\begin{array}{c}\text { Correlation } \\
\text { between CFQ- } \\
\text { and SF- } 36 \text { on } \\
\text { physical } \\
\text { (r=0.81, } p<0.01) \text {, } \\
\text { health } \\
\text { perceptions/ } \\
\text { general health } \\
(\mathrm{r}=0.79, \mathrm{p}<0.01) \\
\text { vitality }(\mathrm{r}=0.84 \text {, } \\
\mathrm{p}<0.01), \text { role/ } \\
\text { role-physical } \\
(\mathrm{r}=0.73, \mathrm{p}<0.01) \text {, } \\
\text { emotional } \\
\text { functioning/ } \\
\text { mental health } \\
(\mathrm{r}=0.74, \mathrm{p}<0.01) \\
\text { and social } \\
(\mathrm{r}=0.57, \mathrm{p}<0.01) \\
\text { domains } \\
\text { Strong } \\
\text { convergence } \\
\text { between child } \\
\text { and parent } \\
\text { proxy reports, } \\
\text { although } \\
\text { children } \\
\text { generally } \\
\text { reported better } \\
\text { HRQoL than } \\
\text { parents }\end{array}$ & $\begin{array}{l}\text { CFQ-R: no } \\
\text { significant } \\
\text { difference } \\
\text { between age } \\
\text { groups (6- } \\
11 \text { years, 12- } \\
13 \text { years versus } \\
>14 \text { years) for all } \\
\text { domains except } \\
\text { treatment } \\
\text { between 6- to } \\
\text { 11-year-olds } \\
\text { and } \\
\geq 14-\text { year-olds } \\
\text { Significant } \\
\text { association } \\
\text { between CFTR } \\
\text { genotype and } \\
\text { CFQ-R scores } \\
\text { (K=9.34, p<0.01) } \\
\text { Strong parent- } \\
\text { child agreement } \\
\text { found for scales } \\
\text { measuring } \\
\text { respiratory } \\
\text { symptoms, but } \\
\text { children } \\
\text { reported more } \\
\text { fatigue and } \\
\text { difficulty } \\
\text { running/walking }\end{array}$ & $\begin{array}{c}\text { Respiratory score } \\
\text { established using } \\
\mathrm{FEV}_{1} \text {; correlation } \\
\text { with } \mathrm{FEV}_{1} \% \text { pred } \\
\mathrm{r}=0.42, \mathrm{p} \text {-value } \\
\mathrm{NR} \text {; correlation } \\
\text { with number of } \\
\text { intravenous } \\
\text { antibiotic courses } \\
\mathrm{r}=-0.27, \mathrm{p} \text {-value } \\
\mathrm{NR}\end{array}$ & NR & Acceptable & $\begin{array}{c}\text { Cronbach's } \\
\alpha=0.6-0.76 \\
\text { with the } \\
\text { exception of } \\
\text { treatment } \\
\text { burden } \\
\text { ( } \alpha=0.44) \\
\text { Parent proxy } \\
\text { report for } \\
\text { CFQ- } R \\
\text { physical, } \\
\text { eating and } \\
\text { respiratory } \\
\text { subscales } \\
\alpha=0.73-0.86\end{array}$ & NR & $\begin{array}{c}\text { Based on } \\
\text { clinician } \\
\text { judgement, a } \\
\text { moderate } \\
\text { change }=0.5 \text { units } \\
\text { and an important } \\
\text { change }=0.8 \text { units } \\
\text { pre- } \& \text { post- } \\
\text { exacerbation }\end{array}$ & NR \\
\hline
\end{tabular}




\begin{tabular}{|c|c|c|c|c|c|c|c|c|c|c|}
\hline Test or tool & $\begin{array}{l}\text { Content } \\
\text { validity }\end{array}$ & $\begin{array}{c}\text { Convergent } \\
\text { validity }\end{array}$ & $\begin{array}{l}\text { Discriminant } \\
\text { validity }\end{array}$ & Concurrent & Predictive & $\begin{array}{l}\text { Intra- or } \\
\text { inter-rater } \\
\text { and } \\
\text { test-retest }\end{array}$ & $\begin{array}{c}\text { Internal } \\
\text { consistency }\end{array}$ & $\begin{array}{l}\text { Measurement } \\
\text { error }\end{array}$ & Responsiveness & $\begin{array}{c}\text { Comments/ } \\
\text { MCID }\end{array}$ \\
\hline CF-QUEST & NR & NR & NR & $\begin{array}{l}\mathrm{r}_{\mathrm{s}} \text { was } 0.951 \text { for } \\
\text { the total } \\
\text { CF-QUEST score, } \\
0.929 \text { for } \\
\text { gastrointestinal } \\
\text { module and } 0.941 \\
\text { for GHQ module } \\
\text { for paper/ } \\
\text { electronic } \\
\text { versions }\end{array}$ & NR & NR & NR & NR & NR & $\begin{array}{l}\text { Excellent } \\
\text { correlation and } \\
\text { agreement of } \\
\text { electronic } \\
\text { version with its } \\
\text { validated } \\
\text { paper } \\
\text { counterpart } \\
\text { Patient } \\
\text { preference } \\
\text { tended } \\
\text { towards } \\
\text { electronic } \\
\text { version }\end{array}$ \\
\hline
\end{tabular}




\begin{tabular}{|c|c|c|c|c|c|c|c|c|c|c|}
\hline Test or tool & $\begin{array}{l}\text { Content } \\
\text { validity }\end{array}$ & $\begin{array}{c}\text { Convergent } \\
\text { validity }\end{array}$ & $\begin{array}{l}\text { Discriminant } \\
\text { validity }\end{array}$ & Concurrent & Predictive & $\begin{array}{l}\text { Intra- or } \\
\text { inter-rater } \\
\text { and } \\
\text { test-retest }\end{array}$ & $\begin{array}{l}\text { Internal } \\
\text { consistency }\end{array}$ & $\begin{array}{l}\text { Measurement } \\
\text { error }\end{array}$ & Responsiveness & $\begin{array}{l}\text { Comments/ } \\
\text { MCID }\end{array}$ \\
\hline FLZ-CF & NR & $\begin{array}{l}\text { Pearson's } \\
\text { correlation } \\
\text { r=0.75 with the } \\
\text { generic } \\
\text { satisfaction } \\
\text { with health } \\
\text { scale of the } \\
\text { FLZ-CF, r } r 0.3 \\
\text { with FEV } \mathrm{V}_{1} \% \\
\text { pred and } \\
\mathrm{r}=-0.26 \text { with } \\
\text { daily time for } \\
\text { home therapy } \\
\text { Leisure time/ } \\
\text { hobbies, } \\
\text { physical } \\
\text { condition, } \\
\text { ability to relax, } \\
\text { energy for life } \\
\text { and satisfaction } \\
\text { with health } \\
\mathrm{r}_{\mathrm{s}}>0.5 \text { with } \\
\text { positive mood } \\
\text { and ability to } \\
\text { relax and SF-36 } \\
\text { physical } \\
\text { functioning, } \\
\text { general health, } \\
\text { vitality, social } \\
\text { function and } \\
\text { mental health }\end{array}$ & $\begin{array}{l}\text { The scale } \\
\text { discriminated } \\
\text { significantly } \\
\text { between } \\
\text { patients with } \\
\text { and without } \\
\text { need for } \\
\text { assistance with } \\
\text { daily life and } \\
\text { between } \\
\text { patients with } \\
\text { and without a } \\
\text { partner }\end{array}$ & $\begin{array}{c}\text { Physical } \\
\text { condition/fitness } \\
\text { and } \mathrm{FEV}_{1} \% \text { pred } \\
\mathrm{r}_{\mathrm{s}}=0.66\end{array}$ & NR & NR & $\begin{array}{l}\text { Cronbach's } \\
\alpha=0.82-0.89\end{array}$ & NR & NR & $\begin{array}{l}\text { Reliable and } \\
\text { valid } \\
\text { Targets general } \\
\text { healthy and } \\
\text { general patient } \\
\text { population } \\
\text { Short enough } \\
\text { to be used as a } \\
\text { screening } \\
\text { instrument }\end{array}$ \\
\hline
\end{tabular}


TABLE 4 Continued

\begin{tabular}{|c|c|c|c|c|c|c|c|c|c|c|}
\hline Test or tool & $\begin{array}{l}\text { Content } \\
\text { validity }\end{array}$ & $\begin{array}{c}\text { Convergent } \\
\text { validity }\end{array}$ & $\begin{array}{l}\text { Discriminant } \\
\text { validity }\end{array}$ & Concurrent & Predictive & $\begin{array}{l}\text { Intra- or } \\
\text { inter-rater } \\
\text { and } \\
\text { test-retest }\end{array}$ & $\begin{array}{l}\text { Internal } \\
\text { consistency }\end{array}$ & $\begin{array}{l}\text { Measurement } \\
\text { error }\end{array}$ & Responsiveness & $\begin{array}{c}\text { Comments/ } \\
\text { MCID }\end{array}$ \\
\hline $\begin{array}{l}\text { Single item } \\
\text { CFQoL } \\
\text { questionnaire }\end{array}$ & NR & $\begin{array}{l}\text { Most of the } \\
\text { CFQoL } \\
\text { variables were } \\
\text { moderately } \\
\text { correlated } \\
(\mathrm{r}=0.38-0.61 \text {, } \\
\mathrm{p}<0.001) \text { with } \\
\text { the single item } \\
\text { scale weakly } \\
\text { correlated with } \\
\text { body image } \\
(\mathrm{r}=0.25), \mathrm{p}<0.01 \\
\text { Higher scores } \\
\text { correlated } \\
\text { negatively with } \\
\text { frequency of } \\
\text { hospital } \\
\text { admissions in } \\
\text { the previous } \\
\text { year }(\mathrm{r}=-0.39 \text {, } \\
\mathrm{p}<0.001)\end{array}$ & $\begin{array}{c}\text { Ability to } \\
\text { distinguish } \\
\text { adult CF } \\
\text { patients with } \\
\text { lower compared } \\
\text { to higher CFQoL } \\
\text { scores }\end{array}$ & $\begin{array}{l}\text { Single-item scale } \\
\text { correlation with } \\
\text { FEV }_{1} \mathrm{r}=0.21\end{array}$ & NR & $\begin{array}{l}\text { ICC } 0.78 \\
(95 \% \mathrm{Cl} \\
0.59-0.88)\end{array}$ & NR & NR & NR & $\begin{array}{l}\text { Acceptable, } \\
\text { valid and } \\
\text { repeatable } \\
\text { measurement } \\
\text { tool that can } \\
\text { be easily used }\end{array}$ \\
\hline CQOLCF & NR & $\begin{array}{c}\text { Correlation } \\
\text { with mental } \\
\text { health } r=0.634 \text {, } \\
\text { emotional } \\
\text { distress } r= \\
-0.687 \text { and } \\
\text { physical health } \\
r=0.049\end{array}$ & NR & NR & NR & NR & $\begin{array}{c}\text { Cronbach's } \\
\alpha=0.909\end{array}$ & NR & NR & $\begin{array}{l}\text { Appears to be } \\
\text { valid, reliable } \\
\text { and internally } \\
\text { consistent } \\
\text { scale }\end{array}$ \\
\hline
\end{tabular}

MCID: minimal clinically important difference; CFIQ: CF Impact Questionnaire; CFOoL: CF QoL Questionnaire; CFQ-R: revised CF Questionnaire; CF-QUEST: electronic version of the CFQoL evaluative self-administered test; FLZ-CF: Questions of Life Satisfaction; CQOLCF: Caregiver QoL CF scale; NR: not reported; SF-36: Short-Form-36 Item Questionnaire; HRQoL: health-related QoL: CFTR: CF transmembrane regulator; FEV ${ }_{1}$ : forced expiratory volume in $1 \mathrm{~s}$; GHQ: General Health Questionnaire; KINDL-R: Child QoL Questionnaire-Revised; ICC: internal consistency coefficient; rs: Spearman's correlation coefficient. 
TABLE 5 Measurement properties of scoring tools based on outcomes reported by people with cystic fibrosis (CF)

\begin{tabular}{|c|c|c|c|c|c|c|c|c|c|c|}
\hline Test or tool & Content validity & $\begin{array}{l}\text { Convergent } \\
\text { validity }\end{array}$ & $\begin{array}{l}\text { Discriminant } \\
\text { validity }\end{array}$ & Concurrent & Predictive & $\begin{array}{l}\text { Intra or } \\
\text { inter-rater } \\
\text { and test- } \\
\text { retest }\end{array}$ & $\begin{array}{l}\text { Internal } \\
\text { consistency }\end{array}$ & $\begin{array}{l}\text { Measurement } \\
\text { error }\end{array}$ & Responsiveness & $\begin{array}{l}\text { Comments/ } \\
\text { MCID }\end{array}$ \\
\hline \multicolumn{11}{|l|}{$\begin{array}{l}\text { Pulmonary } \\
\text { exacerbations }\end{array}$} \\
\hline AWESCORE & NR & NR & NR & $\begin{array}{c}\text { Correlation } \\
\text { of total } \\
\text { AWESCORE } \\
\text { and CFQ-R } \\
\text { scores: } \\
r=0.632 \\
(p=0.003)\end{array}$ & NR & $\begin{array}{c}\text { Pearson's } \\
\text { correlation } \\
\text { coefficient } \\
0.854 \\
p<0.0005\end{array}$ & NR & NR & $\begin{array}{l}\text { For } \\
\text { exacerbation, } \\
\text { score } 47.5 \\
\text { (sD 11.2) at start } \\
\text { of treatment } \\
\text { and 21.6 } \\
\text { (sD 15.6) at end } \\
\text { of treatment } \\
\text { (100=highest } \\
\text { symptom } \\
\text { severity) }\end{array}$ & $\begin{array}{l}11 \text { points } \\
\text { Mean change } \\
\text { of }-16.5 \text { (95\% } \\
\text { CI - } 13.2 \text { to } \\
-19.7 \text { for } \\
\text { exacerbation } \\
\text { reported) } \\
\text { No MCID for } \\
\text { emotional } \\
\text { score }\end{array}$ \\
\hline $\begin{array}{l}\text { CFRSD/ } \\
\text { CFRSD-CRISS }\end{array}$ & $\begin{array}{l}\text { Involved people } \\
\text { with CF in testing } \\
\text { clarity of items }\end{array}$ & $\begin{array}{c}\text { Step-rate } \\
\text { significantly } \\
\text { higher in those } \\
\text { who did NOT } \\
\text { experience } \\
\text { difficulty } \\
\text { breathing, } \\
\text { cough, } \\
\text { tightness or } \\
\text { feeling tired } \\
\text { (respiratory } \\
\text { items) or } \\
\text { feeling } \\
\text { worried, cranky } \\
\text { or frustrated } \\
\text { (emotional } \\
\text { items) }\end{array}$ & $\begin{array}{l}\text { Respiratory } \\
\text { scores } \\
\text { distinguished } \\
\text { between } \\
\text { moderate/ } \\
\text { severe and } \\
\text { mild/severe } \\
\text { disease; } \\
\text { emotional } \\
\text { scores } \\
\text { distinguished } \\
\text { between mild/ } \\
\text { severe disease }\end{array}$ & $\begin{array}{l}\text { Respiratory } \\
\text { and } \\
\text { emotional } \\
\text { score } \\
\text { established } \\
\text { using daily } \\
\text { step count } \\
\text { (not } \mathrm{FEV}_{1} \text { ) }\end{array}$ & NR & $\begin{array}{l}\text { ICC } 0.79 \text { for } \\
\text { respiratory } \\
\text { scale using } \\
\text { a 1-day } \\
\text { interval }\end{array}$ & $\begin{array}{c}\text { Cronbach's } \alpha \\
\text { for } \\
\text { CFRSD-CRISS } \\
\text { was } 0.77\end{array}$ & $\begin{array}{l}\text { Test-retest } \\
\text { reliability after } \\
7-10 \text { days; } 0.9 \\
\text { for the } \\
\text { emotional } \\
\text { and } 0.93 \text { for } \\
\text { the chest } \\
\text { score }\end{array}$ & $\begin{array}{l}\text { Total score } \\
\text { been } \\
\text { demonstrated } \\
\text { to improve over } \\
2 \text { weeks' i.v. } \\
\text { treatment }\end{array}$ & $\begin{array}{c}\text { No MCID } \\
\text { suggested on } \\
\text { the basis of } \\
\text { statistical } \\
\text { analysis, but } \\
\text { MCID }>1 \text { after } \\
2 \text { weeks of } i . v . \\
\text { ABX suggested } \\
\text { based on } \\
\text { experience } \\
\text { with COPD } \\
\text { patients }\end{array}$ \\
\hline
\end{tabular}




\begin{tabular}{|c|c|c|c|c|c|c|c|c|c|c|}
\hline Test or tool & Content validity & $\begin{array}{l}\text { Convergent } \\
\text { validity }\end{array}$ & $\begin{array}{l}\text { Discriminant } \\
\text { validity }\end{array}$ & Concurrent & Predictive & $\begin{array}{l}\text { Intra or } \\
\text { inter-rater } \\
\text { and test- } \\
\text { retest }\end{array}$ & $\begin{array}{l}\text { Internal } \\
\text { consistency }\end{array}$ & $\begin{array}{l}\text { Measurement } \\
\text { error }\end{array}$ & Responsiveness & $\begin{array}{l}\text { Comments/ } \\
\text { MCID }\end{array}$ \\
\hline Symptom score & $\begin{array}{l}\text { Patients not } \\
\text { involved in } \\
\text { construction }\end{array}$ & $\begin{array}{l}\text { All } 4 \text { items } \\
\text { correlated with } \\
\text { each other } \\
r>0.38 ; p<0.001\end{array}$ & NR & $\begin{array}{c}\text { Total score } \\
\text { correlation } \\
\text { with FEV } \mathrm{V}_{1} \text { : } \\
r=-0.41 \text {, } \\
(p<0.0001) \\
\text { and } \\
\text { respiratory } \\
\text { score on } \\
\text { CFQ-R: } \\
r=-0.62 \\
(p<0.001) \\
\text { and CFQ-R: } \\
r=-0.47 \\
(p<0.001)\end{array}$ & NR & NR & NR & NR & NR & \\
\hline ReS-CF & NR & NR & NR & $\begin{array}{c}\text { Correlation } \\
\text { between } \\
\text { ReS-CF and } \\
\text { CFQ-R; } \\
r_{s}=-0.5 \\
(p<0.001)\end{array}$ & NR & $\begin{array}{l}\text { ICCs for } 4 \\
\text { scores }>0.7\end{array}$ & NR & NR & NR & \\
\hline
\end{tabular}




\begin{tabular}{|c|c|c|c|c|c|c|c|c|c|c|}
\hline Test or tool & Content validity & $\begin{array}{l}\text { Convergent } \\
\text { validity }\end{array}$ & $\begin{array}{l}\text { Discriminant } \\
\text { validity }\end{array}$ & Concurrent & Predictive & $\begin{array}{l}\text { Intra or } \\
\text { inter-rater } \\
\text { and test- } \\
\text { retest }\end{array}$ & $\begin{array}{l}\text { Internal } \\
\text { consistency }\end{array}$ & $\begin{array}{l}\text { Measurement } \\
\text { error }\end{array}$ & Responsiveness & $\begin{array}{l}\text { Comments/ } \\
\text { MCID }\end{array}$ \\
\hline SOBQ & NR & $\begin{array}{c}\text { SOBQ scores } \\
\text { correlated } \\
\text { negatively with } \\
\text { physiological } \\
\text { measures of } \\
\text { disease } \\
\text { severity (FVC \% } \\
\text { pred: } r=-0.36 \text {, } \\
p<0.05 \text { and } \\
\mathrm{FEV} \mathrm{V}_{1} \% \text { pred: } \\
\mathrm{r}=-0.5, \mathrm{p}<0.01 \text { ) } \\
\text { Scores } \\
\text { correlated } \\
\text { positively with } \\
\text { Borg scale } \\
\text { ratings of } \\
\text { perceived } \\
\text { breathlessness } \\
\text { after } 6 \mathrm{MWT} \\
\text { and QWB }(\mathrm{r}= \\
-0.41, \mathrm{p}<0.01)\end{array}$ & NR & NR & NR & NR & $\alpha=0.96$ & NR & NR & $\begin{array}{l}\text { MCID: } 5 \text { unit } \\
\text { change }\end{array}$ \\
\hline
\end{tabular}


TABLE 5 Continued

Content validity

Convergent

1

Content validity

Convergent

Discriminant

Concurrent

Predictive

Intra or

Internal

inter-rater consistency

Measurement Responsiveness

error

and test-

Comments/

retest

\begin{tabular}{|c|c|c|c|c|c|c|c|c|c|}
\hline \multicolumn{10}{|l|}{ Pain } \\
\hline BPI & NR & 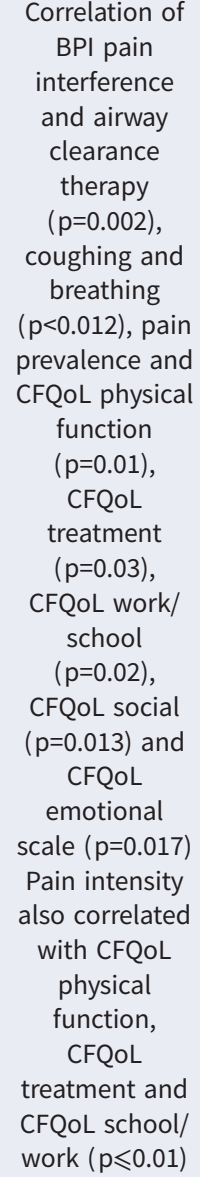 & NR & $\begin{array}{c}\text { Correlation } \\
\text { of BPI pain } \\
\text { prevalence } \\
\text { and sleep } \\
\text { quality } \\
\text { ( } \mathrm{p}=0.045) \text {, } \\
\text { sleep } \\
\text { disturbance } \\
\text { ( } \mathrm{p}<0.001) \text {, } \\
\text { daytime } \\
\text { dysfunction } \\
\text { ( } \mathrm{p}=0.001 \text { ) } \\
\text { and sleep } \\
\text { interference } \\
\text { and global } \\
\text { BPI score } \\
\text { rho-0.56, } \\
\mathrm{p}<0.0001 \\
\text { OR } 1.27 \\
\text { ( } \mathrm{p}=0.012 \text { ) of } \\
\text { impaired } \\
\text { sleep quality } \\
\text { in those } \\
\text { with pain }\end{array}$ & $\begin{array}{l}\text { BPI pain } \\
\text { severity } \\
\text { correlated } \\
\text { with risk of } \\
\text { exacerbations } \\
\text { (OR 1.65, } \\
\text { p=0.04) for } \\
\text { exacerbations } \\
\text { with higher } \\
\text { pain intensity } \\
\text { and OR of } \\
2.28 \text { ( } p=0.008 \text { ) } \\
\text { of death with } \\
\text { higher pain } \\
\text { intensity }\end{array}$ & NR & NR & NR & NR \\
\hline
\end{tabular}




\begin{tabular}{|c|c|c|c|c|c|c|c|c|c|c|}
\hline Test or tool & Content validity & $\begin{array}{l}\text { Convergent } \\
\text { validity }\end{array}$ & $\begin{array}{l}\text { Discriminant } \\
\text { validity }\end{array}$ & Concurrent & Predictive & $\begin{array}{l}\text { Intra or } \\
\text { inter-rater } \\
\text { and test- } \\
\text { retest }\end{array}$ & $\begin{array}{c}\text { Internal } \\
\text { consistency }\end{array}$ & $\begin{array}{l}\text { Measurement } \\
\text { error }\end{array}$ & Responsiveness & $\begin{array}{l}\text { Comments/ } \\
\text { MCID }\end{array}$ \\
\hline DPAQ-CF & NR & 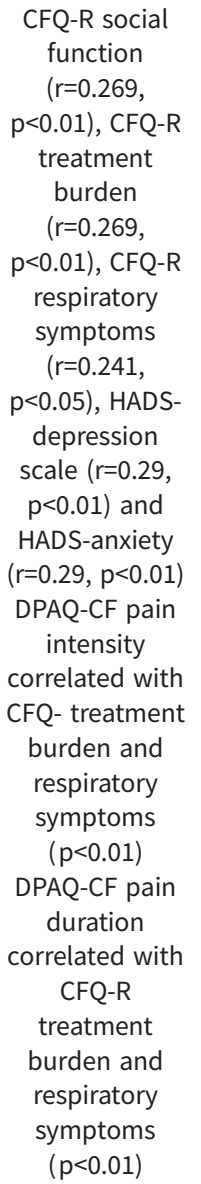 & NR & $\begin{array}{c}\text { Correlation } \\
\text { of pain and } \\
\text { ppFEV }_{1} \\
\mathrm{R}=0.239 \\
\mathrm{P}<0.05\end{array}$ & NR & NR & NR & NR & NR & \\
\hline
\end{tabular}


TABLE 5 Continued

content validity

Content validity

Convergent

Discriminant

Concurrent

Predictive

Intra or

Internal

Measurement Responsiveness

Intra or Internal

Measurement Responsiveness

error

inter-rater

consistency

Comments/ and test-
retest

\begin{tabular}{|c|c|c|c|c|c|c|c|c|c|}
\hline MPI & NR & $\begin{array}{l}\text { Correlation of } \\
\text { BPI pain } \\
\text { severity and } \\
\text { Shwachman } \\
\text { scale history } \\
\text { scale; } r=0.24 \\
(p=0.04) \text { and } \\
\text { BPI pain } \\
\text { interference } \\
\text { and total } \\
\text { Shwachman } \\
\text { score } r=0.2 \\
(p=0.09)\end{array}$ & NR & NR & NR & NR & NR & NR & NR \\
\hline \multicolumn{10}{|l|}{ Abdominal } \\
\hline CF-Abd score & NR & NR & $\begin{array}{c}\text { Differentiated } \\
\text { patients with } \\
\text { CF and healthy } \\
\text { controls with } \\
\text { large effect size } \\
(17.3+1.1 \text { versus } \\
8.0+0.7 \text { points; } \\
\text { p }<0.001 \text {; } \\
\text { Cohen's } d=0.85)\end{array}$ & NR & NR & $\begin{array}{c}\text { ICC } 0.932 \\
(95 \% \mathrm{Cl} \\
0.874-0.963)\end{array}$ & $\begin{array}{l}\text { Cronbach's } \\
\alpha=0.7-0.92\end{array}$ & NR & NR \\
\hline $\begin{array}{l}\text { Gastrointestinal } \\
\text { symptom } \\
\text { tracker }\end{array}$ & NR & $\begin{array}{l}\text { Nutritional } \\
\text { status is } \\
\text { related to } \\
\text { more stable } \\
\text { lung function } \\
\text { and fewer } \\
\text { exacerbations }\end{array}$ & $N R$ & NR & NR & $\begin{array}{l}\text { Reliability } \\
\text { established } \\
\text { based on } \\
\text { test-retest } \\
\text { and internal } \\
\text { consistency } \\
\text { (unspecified) }\end{array}$ & NR & NR & NR \\
\hline
\end{tabular}




\begin{tabular}{|c|c|c|c|c|c|c|c|c|c|c|}
\hline Test or tool & Content validity & $\begin{array}{c}\text { Convergent } \\
\text { validity }\end{array}$ & $\begin{array}{l}\text { Discriminant } \\
\text { validity }\end{array}$ & Concurrent & Predictive & $\begin{array}{l}\text { Intra or } \\
\text { inter-rater } \\
\text { and test- } \\
\text { retest }\end{array}$ & $\begin{array}{c}\text { Internal } \\
\text { consistency }\end{array}$ & $\begin{array}{c}\text { Measurement } \\
\text { error }\end{array}$ & Responsiveness & $\begin{array}{l}\text { Comments/ } \\
\text { MCID }\end{array}$ \\
\hline \multicolumn{11}{|c|}{$\begin{array}{l}\text { Symptom and } \\
\text { impact score }\end{array}$} \\
\hline MSAS-CF & $\begin{array}{l}\text { Developed in } \\
\text { accordance with } \\
\text { COSMIN } \\
\text { recommendations; } \\
\text { patients not } \\
\text { consulted }\end{array}$ & $\begin{array}{c}\text { MSAS-Resp: } \\
\text { correlation } \\
\text { with CFQ-R } \\
(r=-0.60, \\
p<0.05) \text { and } \\
\text { CFQoL ( } r=-0.7 \text {, } \\
\text { p<0.05) } \\
\text { MSAS-Psych: } \\
\text { emotional } \\
\text { scale good } \\
\text { correlation } \\
\text { with CFQ-R } \\
\text { (r=-0.69, } \\
\text { p<0.05) } \\
\text { Poor } \\
\text { correlation } \\
\text { with MSAS-GI: } \\
\text { strongest with } \\
\text { weight (CFQ-R } \\
r=-0.49, \\
\text { p<0.05) } \\
\text { Subscales } \\
\text { moderately } \\
\text { correlated with } \\
\text { symptoms on } \\
\text { CFQ-R and } \\
\text { CFQoL }\end{array}$ & $\begin{array}{c}\text { Respiratory, } \\
\text { gastrointestinal } \\
\text { and psychiatric } \\
\text { scores were } \\
\text { higher in } \\
\text { patients with } \\
\text { low } \mathrm{FEV}_{1}<40 \% \\
\text { pred }(\mathrm{p}<0.05)\end{array}$ & $\begin{array}{c}\text { Correlation } \\
\text { with CFQ-R } \\
\text { respiratory } \\
\text { score } \\
\text { (r=-0.6) and } \\
\text { CFQoL chest } \\
\text { score } \\
(r=-0.7 \text {, } \\
p<0.05) \text { and } \\
\text { CFQ-R } \\
\text { emotional } \\
\text { functioning } \\
\text { score } \\
(r=-0.69 \text {, } \\
p<0.05) . \\
\text { Weak } \\
\text { correlation } \\
\text { with CFQ-R } \\
\text { digestive } \\
\text { score } \\
(r=-0.19 \text {, } \\
p<0.05)\end{array}$ & NR & NR & $\begin{array}{c}\alpha 0.74-0.86 \\
\text { High in all } \\
\text { domains; } \\
\text { MSAS-Physical } \\
\alpha 0.92, \\
\text { MSAS-Psych } \\
\alpha 0.95, \\
\text { MSAS-Global } \\
\alpha 0.82\end{array}$ & NR & NR & $\begin{array}{l}\text { General tool; } \\
\text { not specific for } \\
\text { exacerbations; } \\
\text { originally } \\
\text { developed for } \\
\text { an oncology } \\
\text { population }\end{array}$ \\
\hline
\end{tabular}

MCID: minimal clinically important difference; AWESCORE: Alfred Wellness Score; CFRSD: CF respiratory symptom diary; CRISS: chronic respiratory infection symptom score; ReS-CF: respiratory symptoms in CF tool; SOBQ: Shortness of Breath Questionnaire; BPI: brief pain inventory; DPAQ-CF: Daily Pain Assessment Questionnaire in CF; MPI: multiple pain inventory; CF-Abd: CF abdominal; MSAS: Memorial Symptom Assessment Scale; NR: not reported; FEV ${ }_{1}$ : forced expiratory volume in 1 s; FVC: forced vital capacity; ICC: internal consistency coefficient; ABX: antibiotics ;6MWT: 6-min walk test; QWB: Quality of Well-Being Questionnaire; HADS: Hospital Anxiety and Depression Scale; Resp: respiratory; GI: gastrointestinal; CFQ-R: CF Questionnaire-revised; COSMIN: Consensus-based Standards for the selection of health Measurement INstruments initiative. 
discriminate between people with CF and healthy controls, as well as those at different disease stages based on age, infection and structural abnormalities identified on high-resolution CT imaging or MRI [110]. A correlation with clinical outcomes has not been established.

\section{Imaging scoring tools}

While the Brasfield and Wisconsin CXR scores performed similarly and both have been found to be reproducible (intra-observer agreement $\mathrm{r}=0.86-0.99$ and $0.78-0.96$, respectively) and reliable (inter-rater agreement $0.76-0.90$ and $0.74-0.97$, respectively), they appear to be insensitive to early disease [122]. The correlation between these scores was reported as $\mathrm{r}=0.86, \mathrm{p}<0.0001$. Both scores correlated with lung function $\left(\mathrm{FEV}_{1}\right.$ and forced vital capacity, all $\left.\mathrm{p}<0.001\right)$ [73]. The correlation of scores with $\mathrm{FEV}_{1}$ was highest for the Northern score $(\mathrm{r}=-0.82)$ compared to the Brasfield $(\mathrm{r}=0.81)$ or Crispin-Norman scoring methods ( $\mathrm{r}=-0.83)$ [124].

CT scoring tools have been found to have higher sensitivity for detecting lung disease progression than $\mathrm{FEV}_{1} \%$ pred. The test-retest reliability based on the intraclass correlation coefficient of the PRAGMA-CF score was shown to be $>0.9$ for percentage disease, 0.85 for percentage bronchiectasis and 0.96 for percentage air trapping; the intra-observer reliability was $>0.90$ for bronchiectasis, air trapping and percentage disease [50].

The test-retest reliability of a semi-quantitative MRI score was $r^{2}=0.76(p=0.0047)$ [54] and correlation with $\mathrm{FEV}_{1}$ was $\mathrm{r}=0.81(\mathrm{p}=0.0023)$ [54].

Functional exercise performance

A summary of the measurement properties of tests used to capture functional exercise capacity is provided in table S6.

Many tests capturing functional exercise performance were compared to cardiopulmonary exercise testing (CPET), which has historically been viewed as the gold standard for assessing exercise capacity according to Von Berg et al. [57]. RAND et al. [47] found that the incremental field step test had acceptable concurrent validity compared to CPET in children for measuring peak oxygen uptake, minute ventilation, heart rate, change in oxygen saturation and $\mathrm{CO}_{2}$ ventilation and perceived exertion [47].

Submaximal exercise tests included the 6MWT, 3-min step test (3MST), modified shuttle walk test (MSWT) and 30-s or 1-min sit-to-stand test [57]. Good concurrent validity of the MSWT with maximum oxygen capacity on CPET has been reported; however, results for concurrent validity were inconsistent for the 6MWT and 3MST. The ability of the 6MWT to predict pre-transplant survival was variable [36]. A reduction of $50 \mathrm{~m}$ or more in the modified shuttle test was associated with a hazard ratio of death or lung transplant within 1 year in adults with CF of 1.91 (95\% CI 1.09-3.35, p<0.024) [20]. Convergent validity of 3MST and MSWT with $\mathrm{FEV}_{1}(\mathrm{r}=0.61, \mathrm{p}=0.002)$ was found [36], but this was variable for the 6MWT.

\section{CFTR function tests}

Intestinal current measurement and nasal potential difference (NPD) tests, which directly measure CFTR function, were strongly correlated and have been found to distinguish people with CF from healthy controls ( $k=0.83$ versus $k=0.33$, respectively, $\mathrm{p}<0.001$ ) [68]. Changes in NPD have been reported over 14 days in trials of the CFTR function-modifying drug ivacaftor. Some evidence for the reliability of intestinal organoid volume has been found, but evidence to support its validity has not [68]. Some evidence for the validity and reliability of indirect measures of gastrointestinal CFTR function such as intestinal $\mathrm{pH}$, faecal calprotectin and faecal elastase-1 has been found; however, these data are not described in detail in the review included in our study (table S6).

\section{Sputum tests}

Tests characterising sputum rheology, including viscoelasticity and solid content properties, demonstrated poor to fair test-retest reliability with ICCs ranging from 0.22 to 0.42 (with wide confidence intervals) [46, 103]. Reproducibility of biomarkers in the sputum such as total cell count, neutrophils, tumour necrosis factor- $\alpha$, interleukin-8 and neutrophil elastase was demonstrated in one study [128] as follows: ICC=0.76, 0.82, 0.93, 0.82 and 0.74, respectively; however, there was marked between-patient variability [103, 128].

\section{Measurement error}

The systematic and random error of a patient's score not attributable to true changes in the construct that was measured was poorly reported across all studies (table 4, table 5 and table S6). 
Discussion

While the measurement properties of PROMs evaluating HRQoL in CF studies have been previously evaluated [135], this is the first effort to systematically review evidence of the measurement properties of all tests and tools used in CF studies. A diverse range of tests and tools were identified which vary with respect to their reliability, responsiveness and validity. There was inconsistency in the use of tests and tools to measure the same or similar outcomes across studies. This highlights the need to establish consensus over which outcomes should be measured in CF studies and how they should be measured; this has been recommended by the COSMIN initiative group [136]. Compared to older tools, many recently developed tools incorporate self-reported outcomes by patients (e.g. CFRSD-CRISS, CFQ-R, CF Impact Questionnaire and CF Quality of Life (CFQoL)) and have involved people with CF in their development, consistent with the recommendation made by the US FDA in 2017 [137].

Evidence to support the reliability of spirometry testing was found; this has also been substantiated in other populations, such as in people with other chronic lung disease [138]. Poor $\mathrm{FEV}_{1}$ is strongly correlated with death, progression to lung transplant (most transplant recipients have a $\mathrm{FEV}_{1}<30 \%$ pred) [139] and reduced QoL [110] in people with CF and is also associated with a greater risk of hospitalisation, pulmonary exacerbations and colonisation with Pseudomonas aeruginosa [140]. Compared to crude or percentage predicted $\mathrm{FEV}_{1}$ values, z-scores have been proposed as a less biased and more accurate measure for defining meaningful changes in lung function since they take into account sex and ethnicity in addition to age and height; this approach has been endorsed by the Global Lung Initiative since 2013 [141]. This, however, has not yet been universally adopted as the preferred measure for capturing lung function in CF studies. Consensus regarding the MCID for $\mathrm{FEV}_{1}$ was not identified in this review, but MCIDs have been proposed. In the TRAFFIC and TRANSPORT phase 3 trials, which evaluated lumacaftor-ivacaftor versus placebo for people homozygous for the Phe508del CFTR mutation [142, 143], a mean relative difference of $3.3 \%(2.3-4.4, \mathrm{p}<0.0001)$ and $2.8 \%(1.7-3.8, \mathrm{p}<0.0001)$ was found in those with baseline $\mathrm{FEV}_{1} \geqslant 40 \%$ pred and baseline $\mathrm{FEV}_{1}<40 \%$, respectively. It was proposed that this represents a clinically significant improvement since the annual rate of decline of $\mathrm{FEV}_{1} \%$ pred has been estimated to be $1.92 \%$ per annum for people with CF aged 1824 years $(n=2793)$ and $1.45 \%$ for those aged $>25$ years [144].

While $\mathrm{FEV}_{1}$ has been shown to be reproducible and repeatable in children aged $\geq 6$ years and adults, its variability is affected by the person's age and the severity of their underlying lung disease [110]. In the early stages of $\mathrm{CF}$ disease, $\mathrm{FEV}_{1}$ often remains within the normal range, while in severe lung disease $\mathrm{FEV}_{1}$ is significantly compromised and unlikely to demonstrate variability [89]. LCI testing represents an alternative test for children aged $<6$ years who are incapable of performing spirometry. Since measurement is dependent on body size, the relative rather than the absolute change is considered more appropriate, at least before 6 years of age [145]. LCI has been shown to correlate strongly with structural abnormalities detected on high-resolution CT and abnormal preschool LCI is associated with spirometry deficits performed within 3 years from baseline in school-age children [146]. However, further standardisation and evaluation of the relationship of LCI with morbidity and mortality is warranted.

Evidence of the reliability, responsiveness and validity of two commonly used QoL tools, the CFQ-R and the CFQoL, as well as the CFRSD-CRISS symptom scoring tool has been reported previously and has been substantiated by this review. The content validity (including face validity) of these tools is strengthened by involving people with CF in their development [26]. The CFQ-R has been shown to correlate moderately with $\mathrm{FEV}_{1} \%$ pred [97].

There have been significant advances in treatment and long-term health outcomes for people with CF in recent decades, which raises a concern about the current content validity of some of the outcome scoring tools developed in the second half of the 20th century, many of which did not involve people with CF in their development [43]. Many of these have not undergone sufficient validation and consequently have not been recommended for use in clinical practice or in research.

The use of imaging modalities and scoring tools in CF has evolved with time; however, considerable variability exists between treatment centres, for example whether to use CXR or CT for longitudinal disease monitoring. An important limitation of CXR imaging is its poor sensitivity for detecting structural lung changes in early disease and progression in those with established disease [73]. This modality, however, is still used for monitoring disease progression in some treatment centres, and it has an established role in identifying pathology in the context of an acute clinical deterioration, such as consolidation or pneumothorax. Extensive collaboration has occurred within the CF community to standardise CT and MRI radiological scores, especially in young children, to enable quantification of the degree of structural lung damage. While CT is currently the most sensitive method for detecting structural 
airways disease [147], MRI shows promise because it delivers non-ionising radiation and allows assessment of functional aspects of the lung such as perfusion, pulmonary haemodynamics and ventilation [111]. It may be possible to automate imaging scoring algorithms in the future, which may improve the efficiency and reliability of results. However, further assessment of the validity and reproducibility of MRI scoring tools is required, and the extent to which imaging scores predict clinical outcomes of significance requires further elucidation, including in children [111].

The strengths of this review include the use of a systematic approach to identify studies by two independent reviewers. There were four major limitations. First, tests and tools used in practice in people with CF that have been validated in non-CF populations (e.g. generic scores capturing abdominal symptoms) were considered beyond the scope of this review. Secondly, details about the systematic error (bias) and random error (noise) for each of the tests and tools (i.e. variation beyond that attributable to the outcome of interest) have been poorly described in the literature. Measurement error is an important source of bias; this information is necessary to appraise the quality of tests and tools and should be an important factor influencing selection. Thirdly, medical devices used to capture outcomes were beyond the scope of this review (such as weighing scales or stadiometers used to capture anthropometric outcomes). Finally, given the large scope of this review, an exhaustive critique of the measurement properties of individual tests and tools was not feasible.

\section{Conclusions}

This systematic review highlights the diversity of tests and tools which have been used for outcome measurement in CF studies and their variable characteristics and properties. While there have been concerted efforts within the CF research community to improve and standardise these tests and tools, further work is needed, particularly to optimise tools for outcome measurement in young children and those with mild or severe disease. A consensus set of tests and tools for measurement in CF studies is needed; this should be developed together with people with CF and other relevant stakeholders. This would likely improve the consistency of reporting and measurement of similar outcomes, allowing comparison and synthesis of evidence across studies and improving the value of the research that is conducted.

Provenance: Submitted article, peer reviewed

Acknowledgements: This research did not receive any specific grant from funding agencies in the public, commercial or not-for-profit sectors. C. McLeod is supported by an NHMRC post-graduate scholarship (GNT1150996), and top-up grants from the Wesfarmers Centre and the Perth Children's Hospital Foundation (9772 and 9757). T.L. Snelling is supported by a Career Development Fellowship from the National Health and Medical Research Council (GNT1111657). C.C. Blyth is also supported by the National Health and Medical Research Council (1111596/1173163).

Author contributions: C. McLeod was responsible for the study conceptualisation and overall methodology. C. McLeod and J. Wood were responsible for data curation. T.L. Snelling, C. McLeod, S. Smith, S. Webb, C.C. Blyth, A. Tong, J. Wood, A. Schultz and A.R. Smyth elaborated the study protocol. C. McLeod drafted the manuscript. All authors were involved in the interpretation of data and revision of the manuscript. All authors approved the final manuscript.

Conflict of interest: C. McLeod has nothing to disclose. J. Wood has nothing to disclose. A. Tong has nothing to disclose. A. Schultz reports personal fees from Vertex Pharmaceuticals, outside the submitted work. R. Norman has nothing to disclose. S. Smith has nothing to disclose. C.C. Blyth has nothing to disclose. S. Webb has nothing to disclose. A.R Smyth reports grants from Vertex, speaker honoraria and expenses from TEVA and Novartis, and personal fees from Vertex, outside the submitted work. In addition, A.R. Smyth has a patent "Alkyl quinolones as biomarkers of Pseudomonas aeruginosa infection and uses thereof" issued. T.L. Snelling has nothing to disclose.

Support statement: Funding was received from Perth Children's Hospital Foundation (grants 9772 and 9757), National Health and Medical Research Council (GNT1111657) and Wesfarmers Centre for Vaccines and Infectious Diseases. Funding information for this article has been deposited with the Crossref Funder Registry.

\section{References}

1 Curtis L, Hernandez A, Weinfurt K. Choosing and Specifying Outcomes and Endpoints. Section 1, Introduction. In: NIH Collaboratory Living Textbook of Pragmatic Clinical Trials. Bethesda, MD, NIH, 2020. 
Eisenstein E, Anstrom K, Zozus M, et al. Choosing and Specifying Outcomes and Endpoints. Section 5 , Inpatient endpoints in pragmatic clinical trials. In: NIH Collaboratory Living Textbook of Pragmatic Clinical Trials. Bethesda, MD, NIH, 2020

Mokkink LB, Terwee CB, Patrick DL, et al. The COSMIN study reached international consensus on taxonomy, terminology, and definitions of measurement properties for health-related patient-reported outcomes. $J$ Clin Epidemiol 2010; 63: 737-745.

Fitzpatrick R DC, Buxton MJ, Jones DR. Evaluating patient-based outcome measures for use in clinical trials. Health Technol Assess 1998; 2: i-iv, 1-74.

World Health Organization. WHOQOL: Measuring Quality of Life 2020. www.who.int/healthinfo/survey/ whoqol-qualityoflife/en/ Date last updated: 12 March 2021; date last accessed: 8 August 2020.

Anagnostopoulou P, Yammine S, Schmidt A, et al. False normal Lung Clearance Index in infants with cystic fibrosis due to software algorithms. Pediatr Pulmonol 2015; 50: 970-977.

Archangelidi $\mathrm{O}$, Abbott J, Bryon M, et al. Quality of life in patients with CF using three online research questionnaires: a feasibility study. Pediatr Pulmonol 2019; 54: Suppl. 2, 419.

Bayfield KJ, McGovern M, Simpson AJ, et al. Reliability of measurements using Innocor breath by breath analyser during a maximal exercise test in cystic fibrosis patients. Thorax 2014; 69: A167-A168.

Brody AS, Kosorok MR, Li Z, et al. Reproducibility of a scoring system for computed tomography scanning in cystic fibrosis. J Thorac Imaging 2006; 21: 14-21.

Bullinger M, Petersen C, Muehlan $\mathrm{H}$, et al. A European approach to measuring quality of life in children with chronic conditions: the DISABKIDS experience. Psychother Psychosom 2013; 82: 14.

Button BM, Wilson LM, Finlayson F, et al. Alfred wellness score: effects of pulmonary exacerbations on adult CF patient-reported outcomes-stability and validity. Pediatr Pulmonol 2019; 54: Suppl. 2, 355.

Cebrian M, Ferrero J, Ansotegui E, et al. Comparative study of three quality of life instruments in adolescents and adults with cystic fibrosis. Eur Respir J 2012; 40: Suppl. 56, P3371.

Chaplin JE, Koopman HM, Schmidt S, et al. DISABKIDS Smiley questionnaire: the TAKE 6 assisted health-related quality of life measure for 4 to 7-year-olds. Clin Psychol Psychother 2008; 15: 173-180.

Cheney JL, Saddington H, Shevill E, et al. Development of the pictorial preschool cystic fibrosis questionnaire-revised: child and parent report. Pediatr Pulmonol 2014; 49: Suppl. 38, 435-436.

Chetta A, Pisi G, Zanini A, et al. Six-minute walking test in cystic fibrosis adults with mild to moderate lung disease: comparison to healthy subjects. Respir Med 2001; 95: 986-991.

Connett G, Staab D, Hubert D, et al. The development and use of a pancreatic exocrine insufficiency questionnaire to assess symptoms and their impacts in cystic fibrosis. J Cyst Fibros 2019; 18: Suppl. 1, S136.

Daftary A, Acton J, Heubi J, et al. Fecal elastase-1: utility in pancreatic function in cystic fibrosis. J Cyst Fibros 2006; 5: 71-76.

De Boeck K, Kent L, Davies J, et al. CFTR biomarkers: time for promotion to surrogate end-point? Eur Respir J 2013; 41: 203-216.

Doeleman W, Burghard M, Twisk J, et al. The Modified Shuttle Test to predict survival in cystic fibrosis. J Cyst Fibros 2019; 18: Suppl. 1, S4-S5.

Doeleman WR, Hulzebos E. The minimal clinically important difference for survival in patients with cystic fibrosis. J Cyst Fibros 2018; 17: Suppl. 3, S98-SS9.

Eakin EG, Resnikoff PM, Prewitt LM, et al. Validation of a new dyspnea measure: the UCSD Shortness of Breath Questionnaire. Chest 1998; 113: 619-624.

Gibney KA, Stanojevic S, Salazar J, et al. Validation of a nitrogen (N2) based multiple breath washout technology in healthy children and children with cystic fibrosis. Pediatr Pulmonol 2012; 47: 308.

Gonska T, Ip W, Avolio J, et al. Validation of sweat gland potential difference measurements as a practical in vivo method of assessing CFTR function. Pediatr Pulmonol 2011; 46: 287.

Goss CH, Dellon EP, Lymp JF, et al. Advancing patient reported outcomes in children with cystic fibrosis. Pediatr Pulmonol 2011; 46: 294-295.

Hafen GM, Ranganathan SC, Robertson CF, et al. Clinical scoring systems in cystic fibrosis. Pediatr Pulmonol 2006; 41: 602-617.

Jardine J, Glinianaia SV, McConachie H, et al. Self-reported quality of life of young children with conditions from early infancy: a systematic review. Pediatrics 2014; 134: e1129-e1148.

8 Jaudszus A, Zeman E, Michl R, et al. Comparing abdominal symptoms in cystic fibrosis patients and healthy controls with a novel multimodal questionnaire (CF-Abd Score). J Cyst Fibros 2018; 17: Suppl. 3, S6.

Lowman JD, Moore K, Peeples A, et al. Reliability of musculoskeletal outcome measures. Pediatr Pulmonol 2010; 33: 387.

Madan Kumar H, Prestridge AL. To believe or not to believe first pulmonary function test in cystic fibrosis patients. Pediatr Pulmonol 2011; 46: 341-342.

Mainz JG, Tabori H, Lorenz M, et al. Validity and reliability of a novel multimodal questionnaire for the assessment of abdominal symptoms in people with cystic fibrosis (CFAbd-Score). J Cyst Fibros 2019; 18: Suppl. 1, S33. 
Matouk E, Ghezzo RH, Gruber J, et al. Internal consistency reliability and predictive validity of a modified N. Huang clinical scoring system in adult cystic fibrosis patients. Eur Respir J 1997; 10: 2004-2013.

Matouk E, Ghezzo RH, Gruber J, et al. Construct and longitudinal validity of a modified Huang clinical scoring system in adult cystic fibrosis patients. Eur Respir J 1999; 13: 552-559.

Mayersohn GS, Ramos A, Kim R, et al. Parent and child differences in psychosocial symptom reporting. Pediatr Pulmonol 2016; 51: Suppl. 45, 469.

Modi AC, Quittner AL. Validation of a disease-specific measure of health-related quality of life for children with cystic fibrosis. J Pediatr Psychol 2003; 28: 535-545.

Moran FC, Rodda J. Systematic review of field exercise testing in cystic fibrosis - reliability and validity. Pediatr Pulmonol 2011; 46: 354.

Nyilas S, Bigler A, Yammine S, et al. Alternate gas washout indices: assessment of ventilation inhomogeneity in mild to moderate pediatric cystic fibrosis lung disease. Pediatr Pulmonol 2018; 53: 1485-1491.

Palermo TM, Long AC, Lewandowski AS, et al. Evidence-based assessment of health-related quality of life and functional impairment in pediatric psychology. J Pediatr Psychol 2008; 33: 983-996.

Parekh MH, Ipatova A, Dashputre AA, et al. Quality of life in adult patients with cystic fibrosis - a systematic review. Value Health 2015; 18: A288.

Powers SW, Patton SR, Henry R, et al. A tool to individualize nutritional care for children with cystic fibrosis: reliability, validity, and utility of the CF Individualized NuTritional Assessment of Kids Eating (CF INTAKE). Child Health Care 2005; 34: 113-131.

Quittner AL, Alpern AN, Wolin D, et al. Psychometric analyses of a new Gl symptom tracker for cystic fibrosis. Pediatr Pulmonol 2017; 52: Suppl. 47, 453.

Quittner AL, Biesen J, Marciel K, et al. Health-related quality of life in adolescents with cystic fibrosis: associations with age, gender, nutrition and pulmonary function. Am J Respir Crit Care Med 2020; 201: A1176.

Quittner AL, Marciel KK, Kimberg Cl. Content validity of the cystic fibrosis questionnaire-revised (CFQ-R) Pediatr Pulmonol 2011; 46: 419-420.

Quittner AL, Morris AM, Wainwright C, et al. Development of the preschool cystic fibrosis questionnaire-revised (CFQ-R). Qual Life Res 2015; 24: Suppl. 1, 41.

Radine A, Werner C, Raidt J, et al. Comparison of nocturnal cough analysis in healthy subjects and in patients with cystic fibrosis and primary ciliary dyskinesia: a prospective observational study. Respiration 2019; 97: 60-69.

Radtke T, Boni L, Bohnacker P, et al. The many ways sputum flows - dealing with high within-subject variability in cystic fibrosis sputum rheology. Respir Physiol Neurobiol 2018; 254: 36-39.

Rand S, Prasad SA, Main E. New incremental field step-test (iStep) is valid and feasible in measuring near maximal exercise performance in children with cystic fibrosis. Physiotherapy 2015; 101: eS931-eS932.

Rosenow T, Kuo W, De Bruijne M, et al. A new gold standard for assessing CT in early CF lung disease? Eur Respir J 2014; 44: Suppl. 58, 3446.

Rosenow T, Tiddens H, De Bruijne M, et al. Quantitation of chest CT abnormalities in early life CF: back to the basics. Pediatr Pulmonol 2013; 48: 340.

Rosenow T, Tiddens HA, Oudraad M, et al. PRAGMA: further support for use as a quantitative CT outcome measure. Pediatr Pulmonol 2014; 49: 295.

Sehgal S, Small B, Highland KB. Activity monitors in pulmonary disease. Respir Med 2019; 151: 81-95.

Sheppard E, Chang K, Cotton J, et al. Functional tests of leg muscle strength and power in adults with cystic fibrosis. Respir Care 2019; 64: 40-47.

Sherman AC SS, Reddy R, O'Brien C, et al. Finding meaning in illness: development and initial validation of a measure of sense-seeking and sense-making. Psychosom Med 2013; 3: A133.

Taylor-Cousar JL, Biederer J, Puderbach M, et al. Correlation of a semi-quantitative lung magnetic resonance imaging score with baseline FEV1 in cystic fibrosis. Am J Respir Crit Care Med 2011; 183: A11118.

Toucheque M, Etienne A. Assessment using e-health technologies in pediatric cystic fibrosis: developing a CF-specific module for the quality of life systemic inventory for children (QLSI-C)-iPad version. Pediatr Pulmonol 2014; 49: 441.

Tullis E, Cain E, Griffin K, et al. Validation of an electronic version of the Cystic Fibrosis Quality of life Evaluative Self-administered Test (eCF-QUEST). J Cyst Fibros 2019; 18: Suppl. 1, S179.

Von Berg K. Field exercise tests: which ones, and what can they tell you? Pediatr Pulmonol 2016; 51: Suppl. 45, 187-188.

Ward N, Stiller K, Rowe H, et al. Assessment of cough in cystic fibrosis. Respirology 2016; 21: Suppl. 2, 168. Willgoss TG, Trigg A, Meysner S, et al. Understanding the suitability of cystic fibrosis-specific clinical outcome assessments for clinical trials and to support medical product labeling. Value Health 2015; 18: A286.

Williamson N, Janssen-van Solingen G, Arbuckle R, et al. Psychometric validation of a patient-reported outcome questionnaire in patients with pancreatic exocrine insufficiency. Pancreatology 2017; 17: Suppl. 3, S19-S20. 
Wilschanski M, Yaakov Y, Omari I, et al. Comparison of nasal potential difference and intestinal current measurements as surrogate markers for CFTR function. J Pediatr Gastroenterol Nutr 2016; 63: e92-e97.

Ahrens RC, Standaert TA, Launspach J, et al. Use of nasal potential difference and sweat chloride as outcome measures in multicenter clinical trials in subjects with cystic fibrosis. Pediatr Pulmonol 2002; 33: 142-150.

Aigner C JP, Seebacher G, Mazhar S, et al. Cystic fibrosis and lung transplantation - determination of the survival benefit. Wien Klin Wochenschr 2004; 116: 318-321.

Alpern AN, Brumback LC, Ratjen F, et al. Initial evaluation of the Parent Cystic Fibrosis Questionnaire-Revised (CFQ-R) in infants and young children. J Cyst Fibros 2015; 14: 403-411.

Andrade Lima C, Dornelas de Andrade A, Campos SL, et al. Six-minute walk test as a determinant of the functional capacity of children and adolescents with cystic fibrosis: a systematic review. Respir Med 2018; 137: 83-88.

Balfour L, Amstrong M, Holly C, et al. Development and psychometric validation of a cystic fibrosis knowledge scale. Respirology 2014; 19: 1209-1214.

Bell SC, Mainz JG, MacGregor G, et al. Patient-reported outcomes in patients with cystic fibrosis with a G551D mutation on ivacaftor treatment: results from a cross-sectional study. BMC Pulm Med 2019; 19: 146.

Bodewes FA, Verkade HJ, Taminiau JA, et al. Cystic fibrosis and the role of gastrointestinal outcome measures in the new era of therapeutic CFTR modulation. J Cyst Fibros 2015; 14: 169-177.

Boling W, Macrina DM, Clancy JP. The Caregiver Quality of Life Cystic Fibrosis (CQOLCF) scale: modification and validation of an instrument to measure quality of life in cystic fibrosis family caregivers. Qual Life Res 2003; 12: 1119-1126.

Boon M, Claes I, Havermans T, et al. Assessing gastro-intestinal related quality of life in cystic fibrosis: validation of PedsQL GI in children and their parents. PLoS One 2019; 14: e0225004.

Bradley J, Dempster M, Wallace E, et al. The adaptations of a quality of life questionnaire for routine use in clinical practice: the Chronic Respiratory Disease Questionnaire in cystic fibrosis (CRDQ). Qual Life Res 1999; 8: 65-71.

Buchs C, Coutier L, Vrielynck S, et al. An impulse oscillometry system is less efficient than spirometry in tracking lung function improvements after intravenous antibiotic therapy in pediatric patients with cystic fibrosis. Pediatr Pulmonol 2015; 50: 1073-1081.

Cleveland RH, Stamoulis C, Sawicki G, et al. Brasfield and Wisconsin scoring systems have equal value as outcome assessment tools of cystic fibrosis lung disease. Pediatr Radiol 2014; 44: 529-534.

Cullen DL, Rodak B. Clinical utility of measures of breathlessness. Respir Care 2002; 47: 986-993.

dos Santos DM, Deon KC, Bullinger M, et al. Validity of the DISABKIDS-Cystic Fibrosis Module for Brazilian children and adolescents. Rev Lat Am Enfermagem 2014; 22: 819-825.

Driscoll KA, Modi AC, Filigno SS, et al. Quality of life in children with CF: psychometrics and relations with stress and mealtime behaviors. Pediatr Pulmonol 2015; 50: 560-567.

Edwards TC, Emerson J, Genatossio A, et al. Initial development and pilot testing of observer-reported outcomes (ObsROs) for children with cystic fibrosis ages 0-11 years. J Cyst Fibros 2018; 17: 680-686.

Eidt-Koch D, Mittendorf T, Greiner W. Cross-sectional validity of the EQ-5D-Y as a generic health outcome instrument in children and adolescents with cystic fibrosis in Germany. BMC Pediatr 2009; 9: 55.

Gee L, Abbott J, Conway SP, et al. Development of a disease specific health related quality of life measure for adults and adolescents with cystic fibrosis. Thorax 2000; 55: 946-954.

Gee L, Abbott J, Conway SP, et al. Validation of the SF-36 for the assessment of quality of life in adolescents and adults with cystic fibrosis. J Cyst Fibros 2002; 1: 137-145.

Goldbeck L, Schmitz TG. Comparison of three generic questionnaires measuring quality of life in adolescents and adults with cystic fibrosis: the 36-item short form health survey, the quality of life profile for chronic diseases, and the questions on life satisfaction. Qual Life Res 2001; 10: 23-36.

Goldbeck L, Schmitz TG, Henrich G, et al. Questions on life satisfaction for adolescents and adults with cystic fibrosis: development of a disease-specific questionnaire. Chest 2003; 123: 42-48.

Gruet M, Brisswalter J, Mely L, et al. Use of the peak heart rate reached during six-minute walk test to predict individualized training intensity in patients with cystic fibrosis: validity and reliability. Arch Phys Med Rehabil 2010; 91: 602-607.

4 Gruet M, Peyre-Tartaruga LA, Mely L, et al. The 1-minute sit-to-stand test in adults with cystic fibrosis: correlations with cardiopulmonary exercise test, 6-minute walk test, and quadriceps strength. Respir Care 2016; 61: 1620-1628.

Hoffman BM, Stonerock GL, Smith PJ, et al. Development and psychometric properties of the Pulmonaryspecific Quality-of-Life Scale in lung transplant patients. J Heart Lung Transplant 2015; 34: 1058-1065.

Hulzebos E, Dadema T, Takken T. Measurement of physical activity in patients with cystic fibrosis: a systematic review. Expert Rev Respir Med 2013; 7: 647-653.

Johnson CD, Williamson N, Janssen-van Solingen G, et al. Psychometric evaluation of a patient-reported outcome measure in pancreatic exocrine insufficiency (PEI). Pancreatology 2019; 19: 182-190. 
Kaplan RM, Anderson JP, Wu AW, et al. The Quality of Well-being Scale. Applications in AIDS, cystic fibrosis, and arthritis. Med Care 1989; 27: Suppl 3, S27-S43.

Kent L, Reix P, Innes JA, et al. Lung clearance index: evidence for use in clinical trials in cystic fibrosis. J Cyst Fibros 2014; 13: 123-138.

Lee AL, Rawlings S, Bennett KA, et al. Pain and its clinical associations in individuals with cystic fibrosis: a systematic review. Chron Respir Dis 2016; 13: 102-117.

Matecki S, Kent $\mathrm{L}$, de Boeck $\mathrm{K}$, et al. Is the raised volume rapid thoracic compression technique ready for use in clinical trials in infants with cystic fibrosis? J Cyst Fibros 2016; 15: 10-20.

McCarrier KP, Hassan M, Hodgkins P, et al. The Cystic Fibrosis Impact Questionnaire: qualitative development and cognitive evaluation of a new patient-reported outcome instrument to assess the life impacts of cystic fibrosis. J Patient Rep Outcomes 2020; 4: 36.

Mesbahi M, Shteinberg M, Wilschanski M, et al. Changes of CFTR functional measurements and clinica improvements in cystic fibrosis patients with non p.Gly551Asp gating mutations treated with ivacaftor. J Cyst Fibros 2017; 16: 45-48.

Munzenberger PJ, Van Wagnen CA, Abdulhamid I, et al. Quality of life as a treatment outcome in patients with cystic fibrosis. Pharmacotherapy 1999; 19: 393-398.

Padilla A, Olveira G, Olveira C, et al. [Validity and reliability of the St George's Respiratory Questionnaire in adults with cystic fibrosis]. Arch Bronconeumol 2007; 43: 205-211.

Pakhale S, Armstrong M, Holly C, et al. Assessment of stigma in patients with cystic fibrosis. BMC Pulm Med 2014; 14: 76.

Quittner AL, Buu A, Messer MA, et al. Development and validation of The Cystic Fibrosis Questionnaire in the United States: a health-related quality-of-life measure for cystic fibrosis. Chest 2005; 128: 2347-2354.

Quittner AL, Sawicki GS, McMullen A, et al. Erratum to: Psychometric evaluation of the Cystic Fibrosis Questionnaire-Revised in a national, US sample. Qual Life Res 2012; 21: 1279-1290.

Quon BS, Patrick DL, Edwards TC, et al. Feasibility of using pedometers to measure daily step counts in cystic fibrosis and an assessment of its responsiveness to changes in health state. J Cyst Fibros 2012; 11: 216-222.

Radtke T, Hebestreit H, Puhan MA, et al. The 1-min sit-to-stand test in cystic fibrosis - insights into cardiorespiratory responses. J Cyst Fibros 2017; 16: 744-751.

Radtke T, Puhan MA, Hebestreit $\mathrm{H}$, et al. The 1-min sit-to-stand test - a simple functional capacity test in cystic fibrosis? J Cyst Fibros 2016; 15: 223-226.

Rosenow T, Oudraad MC, Murray CP, et al. PRAGMA-CF. A quantitative structural lung disease computed tomography outcome in young children with cystic fibrosis. Am J Respir Crit Care Med 2015; 191: 1158-1165.

Sagel SD, Chmiel JF, Konstan MW. Sputum biomarkers of inflammation in cystic fibrosis lung disease. Proc Am Thorac Soc 2007; 4: 406-417.

patients with cystic fibrosis? Front Pharmacol 2012; 3: 38.

Sawicki GS, Sellers DE, Robinson WM. Self-reported physical and psychological symptom burden in adults with cystic fibrosis. J Pain Symptom Manage 2008; 35: 372-380.

during a cystic fibrosis exacerbation. Respir Care 2018; 63: 353-366.

Simeoni MC, Schmidt S, Muehlan H, et al. Field testing of a European quality of life instrument for children and adolescents with chronic conditions: the 37-item DISABKIDS Chronic Generic Module. Qual Life Res 2007; 16: 881-893.

Sockrider MM, Swank PR, Seilheimer DK, et al. Measuring clinical status in cystic fibrosis: internal validity and reliability of a modified NIH score. Pediatr Pulmonol 1994; 17: 86-96.

Solomon GM, Liu B, Sermet-Gaudelus I, et al. A multiple reader scoring system for nasal potential difference parameters. J Cyst Fibros 2017; 16: 573-578.

\section{6-423.} can be counted? J Cyst Fibros 2017; 16: 175-185.

in cystic fibrosis studies. What counts, and fibrosis: convergent validity with parent-reports and objective measures of pulmonary health. $J$ Develop Behav Pediatr 2013; 34: 252-261.

13 Usatin D, Yen EH, McDonald C, et al. Differences between WHO and CDC early growth measurements in the assessment of Cystic Fibrosis clinical outcomes. J Cyst Fibros 2017; 16: 503-509.

VanDevanter DR, Heltshe SL, Spahr J, et al. Rationalizing endpoints for prospective studies of pulmonary exacerbation treatment response in cystic fibrosis. J Cyst Fibros 2017; 16: 607-615.

Ward N, Stiller K, Rowe H, et al. The psychometric properties of the Leicester Cough Questionnaire and Respiratory Symptoms in CF tool in cystic fibrosis: a preliminary study. J Cyst Fibros 2017; 16: 425-432. 
116 Wenninger $\mathrm{K}$, Weiss $\mathrm{C}$, Wahn $\mathrm{U}$, et al. Body image in cystic fibrosis - development of a brief diagnostic scale. J Behav Med 2003; 26: 81-94.

117 Yohannes AM, Dodd M, Morris J, et al. Reliability and validity of a single item measure of quality of life scale for adult patients with cystic fibrosis. Health Qual Life Outcomes 2011; 9: 105.

118 Young NL, Varni JW, Snider L, et al. The Internet is valid and reliable for child-report: an example using the Activities Scale for Kids (ASK) and the Pediatric Quality of Life Inventory (PedsQL). J Clin Epidemiol 2009; 62: 314-320.

119 Gruet M. The 1-minute sit-to-stand test in adults with cystic fibrosis: correlations with cardiopulmonary exercise test, 6-minute walk test, and quadriceps strength. Respir Care 2016; 61: 1620-1628.

120 U.S. National Library of Medicine. Clinical Trials Register. www.clinicaltrials.gov/ Date last accessed: 2 October 2020.

121 Aigner C, Jaksch P, Seebacher G, et al. Cystic fibrosis and lung transplantation - determination of the survival benefit. Wien Klin Wochenschr 2004; 116: 318-321.

122 Brasfield D, Hicks G, Soong S, et al. The chest roentgenogram in cystic fibrosis: a new scoring system. Pediatrics 1979; 63: 24-29.

123 Chrispin AR, Norman AP. The systematic evaluation of the chest radiograph in cystic fibrosis. Pediatr Radiol 1974; 2: 101-105.

124 Conway SP, Pond MN, Bowler I, et al. The chest radiograph in cystic fibrosis: a new scoring system compared with the Chrispin-Norman and Brasfield scores. Thorax 1994; 49: 860-862.

125 Dill EJP, Dawson RP, Sellers DEP, et al. Longitudinal trends in health-related quality of life in adults with cystic fibrosis. Chest 2013; 144: 981-989.

126 Kerem E, Reisman J, Corey M, et al. Prediction of mortality in patients with cystic fibrosis. N Engl J Med 1992; 326: 1187-1191.

127 Liou TG, Adler FR, FitzSimmons SC, et al. Predictive 5-year survivorship model of cystic fibrosis. Am J Epidemiol 2001; 153: 345-352.

128 Smountas AA, Lands LC, Mohammed SR, et al. Induced sputum in cystic fibrosis: within-week reproducibility of inflammatory markers. Clin Biochem 2004; 37: 1031-1036.

129 Weatherly MR, Palmer CG, Peters ME, et al. Wisconsin cystic fibrosis chest radiograph scoring system. Pediatrics (Evanston) 1993; 91: 488.

130 American Thoracic Society. Cystic Fibrosis Questionnaire (CFQ) and Cystic Fibrosis Questionnaire Revised (CFQ-R). https://qol.thoracic.org/sections/instruments/ae/pages/cfq-cfq-r.html Date last updated: April 2002; date last accessed: 29 September 2020.

131 U.S. Food and Drug Administration. Table of surrogate endpoints that were the basis of drug approval or licensure. www.fda.gov/drugs/development-resources/table-surrogate-endpoints-were-basis-drug-approvalor-licensure Date last updated: 20 August 2020; date last accessed: 27 September 2020.

132 European Medicines Agency. Report of the workshop on endpoints for cystic fibrosis clinical trials. www.ema.europa.eu/en/documents/report/report-workshop-endpoints-cystic-fibrosis-clinical-trials_en.pdf Date last updated: 29 November 2012; date last accessed: 13 October 2020.

133 Blackwell LS, Quittner AL. Daily pain in adolescents with CF: effects on adherence, psychological symptoms, and health-related quality of life. Pediatr Pulmonol 2015; 50: 244-251.

134 Henry B, Aussage P, Grosskopf C, et al. Development of the Cystic Fibrosis Questionnaire (CFQ) for assessing quality of life in pediatric and adult patients. Qual Life Res 2003; 12: 63-76.

135 Ratnayake I, Ahern S, Ruseckaite R. A systematic review of patient-reported outcome measures (PROMs) in cystic fibrosis. BMJ Open 2020; 10: e033867.

136 COSMIN. www.cosmin.nl/

137 US Department of Health and Human Services. Multiple Endpoints for Clinical Trials: Guidance for Industry. www.fda.gov/media/102657/download Date last updated: January 2017; date last accessed: 15 October 2020.

138 Graham BL, Steenbruggen I, Miller MR, et al. Standardization of Spirometry 2019 Update. An Official American Thoracic Society and European Respiratory Society Technical Statement. Am J Respir Crit Care Med 2019; 200: e70-e88.

139 Cystic Fibrosis Foundation Patient Registry. 2018 Annual Data Report. Bethesda, MD, National Institutes of Health, 2018.

140 Szczesniak R, Heltshe SL, Stanojevic S, et al. Use of FEV1 in cystic fibrosis epidemiologic studies and clinical trials: a statistical perspective for the clinical researcher. J Cyst Fibros 2017; 16: 318-326.

141 Stanojevic S, Quanjer P, Miller MR, et al. The Global Lung Function Initiative: dispelling some myths of lung function test interpretation. Breathe 2013; 9: 462-474.

142 Wainwright CE, Elborn JS, Ramsey BW, et al. Lumacaftor-ivacaftor in patients with cystic fibrosis homozygous for Phe508del CFTR. N Engl J Med 2015; 373: 220-231.

143 Elborn JS, Ramsey BW, Boyle MP, et al. Efficacy and safety of lumacaftor/ivacaftor combination therapy in patients with cystic fibrosis homozygous for Phe508del CFTR by pulmonary function subgroup. Lancet Respir Med 2016; 4: 617-626. 
144 Konstan MW, Wagener JS, VanDevanter DR, et al. Risk factors for rate of decline in FEV1 in adults with cystic fibrosis. J Cyst Fibros 2012; 11: 405-411.

145 Fretzayas A, Douros K, Moustaki M, et al. Applications of lung clearance index in monitoring children with cystic fibrosis. World J Clin Pediatr 2019; 8: 15-22.

146 Hardaker KM, Panda H, Hulme K, et al. Abnormal preschool Lung Clearance Index (LCI) reflects clinical status and predicts lower spirometry later in childhood in cystic fibrosis. J Cyst Fibros 2019; 18: 721-727.

147 Bouma N JH, Andrinopoulou ER, Tiddens H. Airway disease on chest computed tomography of preschool children with cystic fibrosis is associated with school aged bronchiectasis. Pediatr Pulmonol 2020; 55: 141-148. 